\title{
TİCARET ŞİRKETLERI BAKIMINDAN TÂBIIYYET PLANLAMASI VE ULUSLARARASI YATIRIM HUKUKU AÇISINDAN DOĞURDUĞU SONUÇLAR
}

Talat KAYA*

\section{$\ddot{O} Z$}

Ulusal ve uluslararası hukukta ticaret şirketlerinin tâbiiyetini tayin açısından çoğunlukla kuruluş yeri ve merkez yeri esasları kullanılmaktadır. Uluslararası yatırım anlaşmaları da yatırımc şirketleri bu esaslar temelinde tanımlamaktadır. Hakem heyetlerinin ise kuruluş yeri esast ile herhangi bir nitelemeden yoksun merkez yeri esasını biçimsel olarak yorumlaması tâbiiyet planlamasına olanak sağlamıştır. Tâbiiyet planlaması, şirketlerin yatırımın başlangıcı veya sonrasındaki bir dönemde elverişli yatırım iklimi velveya hukuki alt yapı sunan bir devletin tâbiiyetini edinimi olarak tanımlanabilir. Şirketler uluslararası yatırım hukuku bağlamında genellikle yatırım tahkimine başvurma hakkına kavuşmak amacıyla tâbiiyet planlamasına girişmektedir. Ancak kaynak ülke ile gerçek bir bă̆l bulunmayan tabela şirketler tarafindan başlatılan tahkim davaları tâbiiyet planlaması uygulamasına karşı bir tepkiyi de beraberinde getirmiştir. Bu tepki iki şekilde ortaya çıkmıştır. Illk olarak yatırım tahkimi davalarında ev sahibi devletlerin itirazları üzerine bazı hakem heyetleri tâbiiyet planlamasının amacı ve/veya gerçekleştirime zamanını dikkate alarak bu uygulamayı hakkın kötüye kullanılması yasağ içerisinde değerlendirmiştir. Ikinci olarak ise devletler son dönemde yapmıs oldukları ikili ve çok tarafl yatırım anlaşmalarında yatırımcı tanımını daraltmış ve/veya tâbiiyet planlamasına karşı faydaların reddi hükümlerine yer vermişlerdir.

Anahtar Kelimeler: Şirket tâbiiyeti, tâbiiyet planlaması, yatırım tahkimi, hakkın kötüye kullanılması, faydaların reddi

\section{CORPORATE NATIONALITY PLANNING AND ITS CONSEQUENCES FOR INTERNATIONAL INVESTMENT LAW}

\section{ABSTRACT}

In national and international law, place of incorporation and seat are mostly used criteria in determining corporate nationality. International investment agreements

* Dr. Öğr. Üyesi, Ankara Sosyal Bilimler Üniversitesi Hukuk Fakültesi, Milletlerarası Özel Hukuk Anabilim Dal1/ ANKARA e-posta: talat.kaya@asbu.edu.tr

ORCID: 0000-0002-5535-6819

DOI : 10.34246/ahbvuhfd. 1018657

Yayın Kuruluna Ulaştığı Tarih $\quad$ :05/07/2021

Yayınlanmasının Uygun Görüldüğü Tarih: 13/10/2021 
also define corporate investors based on these criteria. Besides, formal interpretation of place of incorporation criterion and the seat criterion without any qualification by the arbitral tribunals has allowed nationality planning. Nationality planning can be defined as the acquisition of the nationality of a state that provides a favorable investment climate and/or legal infrastructure for corporates at the beginning of the investment or at a later period. In the context of international investment law, companies usually engage in nationality planning to obtain the right to apply for investment arbitration. However, arbitration proceedings initiated by shell companies that have no genuine link to the home state have brought a reaction against the practice of nationality planning. This reaction occurred in two ways. First, on the objections of the host states, some arbitral tribunals, considering the purpose and/ or the time of realization of the nationality planning, have deemed this practice as abuse of rights. Secondly, states have narrowed the definition of investor and/or put denial of benefits provisions against nationality planning in their recent bilateral and multilateral investment agreements.

Keywords: Corporate nationality, nationality planning, investment arbitration, abuse of rights, denial of benefits

\section{GİRIŞ}

Yatırımcı tanımı, uluslararası yatırım hukukunun temel meselelerinden bir tanesidir. Zira yatırım anlaşmalarında yer verilen esasa dair standartlardan ancak anlaşma tarafı devletlerin tâbiiyetinde bulunan yatırımcılar yararlanabilmektedir ${ }^{1}$. Yine yatırımcılar tarafından başlatılan uluslararası tahkim davalarında hakem heyetlerinin kişi bakımından yargı yetkisi davacının tâbiiyeti ile yakından ilgilidir² ${ }^{2}$ Bu anlamda, yatırım tahkimine başvurabilmek için kural olarak yatırımcının kaynak devletin (home state) tâbiiyetinde olduğunu göstermesi gerekir³ ${ }^{3}$ Uluslararası yatırım anlaşmalarında yatırımcı

Campbell McLachlan/ Laurence Shore/ Matthew Weiniger, International Investment Arbitration: Substantive Principles, 2nd Edition, 2017, s. 156; Christoph Schreuer, "Nationality Planning" in Arthur W. Rovine (Ed), Contemporary Issues in International Arbitration and Mediation: Contemporary Issues in International Arbitration and Mediation: The Fordham Papers, 2012, s. 17.

2 McLachlan/ Shore/ Weiniger, s. 156; Schreuer s. 17.

3 Philipp Janig, "Cynicism and Nationality Planning in International Investment Law", in Björnstjern Baade Dana Burchardt/ Prisca Feihle/ Alicia Köppen/ Linus Mührel/ Lena Riemer/ Raphael Schäfer (Eds.), Cynical International Law? Beiträge zum ausländischen öffentlichen Recht und Völkerrecht (Veröffentlichungen des Max-Planck-Instituts für ausländisches öffentliches Recht und Völkerrecht), vol 296, Springer, 2021, s. 310. 
kavramı geleneksel olarak, anlaşmaya taraf âkit devletlerin vatandaşı olan gerçek kişileri, yine âkit taraf tâbiiyetinde bulunan şirketler gibi tüzel kişileri ve iş ortaklıkları gibi tüzel kişiliği olmayan teşekkülleri kapsayacak şekilde geniş olarak tanımlanmaktadır ${ }^{4}$. Bununla birlikte uluslararası yatırımlar çoğunlukla ticaret şirketleri tarafindan yapılmaktadır. Dolayısıyla uluslararası yatırım anlaşmaları ile tanınan haklardan yararlananlar da esas itibariyle ticaret şirketleridir. Bu durum göz önüne alındığında, uluslararası yatırım hukuku açısından şirketlerin tâbiiyetinin tayini hayati önemi haizdir ${ }^{5}$.

Uluslararası yatırım anlaşmalarında şirketlerin tâbiiyetinin tayini açısından çoğunlukla kuruluş ve merkez yerleri esasları kullanılmakta, bazı anlaşmalarda ise bu esasların yanında sınırlı olarak kontrol esasına yer verilmektedir ${ }^{6}$. Kuruluş yeri esas1, bir devletin kanunlarına uygun olarak kurulmuş olan şirketlerin o ülkenin tâbiiyetinde olduğunu kabul etmektedir. Bu manada şirket, esas faaliyetlerini kurulduğu ülkede yürütüp yürütmemesine bakılmaksızın, o ülkenin imzalamış olduğu yatırım anlaşmalarının sağladığ 1 haklardan yararlanma imkânına kavuşmaktadır. Merkez yeri esası ise yatırım anlaşmaları ile tanınan haklardan yararlanmak bakımından, şirket merkezinin âkit taraf ülkesinde olmasını aramaktadır. Daha sınırlı bir uygulamaya sahip kontrol esası ise ev sahibi devlet (host state) veya üçüncü ülke tâbiiyetinde olmakla birlikte, kaynak devletin tâbiiyetinde bulunan kişiler tarafindan kontrol edilen şirketlerin yatırım anlaşmaları kapsamına alınmasını sağlayan bir mekanizmadır?.

4 Bu şekilde bir tanımlama örneği için bkz. Türkiye-Azerbaycan Yatırımların Karşılıklı ve Teşviki Anlaşması m. 1/2: "Yatırımcı" terimi: diğer Akit Tarafin ülkesinde bu Akit Tarafin mevzuatına uygun olarakyatırım yapmış, (a) bir Akit Tarafin kanunlarına göre vatandaşliğını haiz olan gerçek kişileri,(b) Akit Taraflardan birinin yürürlükteki hukuku çerçevesinde kurulmuş veya teşekkül etmiş ve kayttl yönetim merkezleri ile birlikte yeterli seviyedeki faaliyetleri söz konusu Akit Tarafin ülkesinde bulunan ve diğer Akit Tarafin ülkesinde, o ülkenin mevzuatı ile uyumlu olarak yatırım yapan şirketleri, firmaları veya iş ortaklıklarını ifade eder. Ĕger yatırımcı yatırımın yapıldığ ülke ile diplomatik ilişsisi bulunmayan üçüncü bir ülkenin vatandaşllğııı haiz kişilere ait ise veya bu kişilerce kontrol edilmekte ise bu yatırımcı işbu Anlaşmadan faydalanamaz."

5 Simon Foote QC, The Bona Fide Investor: Corporate Nationality and Treaty Shopping in Investment Treaty Law, PhD Thesis, Victoria University of Wellington, Faculty of Law, 2020, s. 7.

6 McLachlan/ Shore/ Weiniger, s. 157.

7 Kontrol esasının yatırım tahkimi açısından sınırlı bir uygulamaya sahip olması, tâbiiyet planlaması kapsamında ise tatbikinin olmaması nedeniyle, bu esas inceleme kapsamı dişında tutulmuştur. Yine de incelemede tâbiiyet konusunun anlaşılması bakımından yeri geldiğinde bu amaca matuf olarak kontrol esasına da temas edilmiştir. 
Uygulamada ise şirketlerin tâbiiyetinin tayini açısından hakemlerce yapılan araştırma çoğunlukla biçimsel bir incelemenin ötesine geçmemekte, şirketin kurulduğu veya merkez yerinin bulunduğu ülke ile gerçek bağının (genuie link) olup olmadığı üzerinde durulmamaktadır. Yatırımcı tâbiiyetinin biçimsel olarak ele alınması yatırım tahkimine başvurma hakkı başta olmak üzere, uluslararası yatırım anlaşmalarının tanımış olduğu olanaklardan yararlanacak yatırımcı şirketlerin tespiti konusunda uygulayıcılara kesinlik ve öngörülebilirlik sağlamaktadır. Bununla birlikte şirket tâbiiyetinin bu şekilde ele alınması; ev sahibi veya üçüncü bir devlet tâbiiyetinde bulunmaları nedeniyle uluslararası yatırım anlaşmasının sağlamış olduğu imkânlardan yararlanamayan ticaret şirketlerinin, yatırımın başlangıcında veya sonrasında yatırım sayılan varlıklarını diğer âkit taraf ülkesinde var olan veya yeni kurulan kabuk veya tabela şirket (shell company) altında yapılandırmak/ yeniden yapılandırmak suretiyle anlaşma kapsamına girmesine olanak sağlamaktadır ${ }^{8}$. Uygun tâbiiyet (nationality of convenience) veya tâbiiyet planlaması (nationality planning) olarak anılan bu uygulamaya özellikle yatırım tahkimine başvurma hakkına kavuşmak amacıyla girişilmektedir? Şirketlerin vergisel avantajlar ve yatırım anlaşmalarının sağladığı hak ve imkânlardan yararlanmak gibi çeşitli nedenlerle tâbiiyetlerini değiştirmeleri veya yatırımlarını yapılandırmaları kural olarak meşrudur ${ }^{10}$. Ancak tâbiiyet planlamasının amacı ve gerçekleştirilme zamanı başta olmak üzere kullanılma şekli bazı durumlarda suistimalleri beraberinde getirmektedir. Bu manada tâbiiyet planlaması anlaşma ile sağlanan kolaylıkları elde etmeyi amaçlayan anlaşma seçme (treaty shopping) ayarlamasına dönüşebilmektedir ${ }^{11}$.

Son 20 yılda şirketler tarafından tâbiiyet planlamasına dayalı olarak yatırım tahkimine sıklıkla başvurulması, uygulamaya karşı bir tepkiyi de beraberinde getirmiştir. Bu tepki iki şekilde ortaya çıkmıştır. İlk olarak yatırım tahkimi davalarında ev sahibi devletlerin itirazları üzerine bazı hakem heyetleri tâbiiyet planlamasının amacı ve/veya gerçekleştirilme zamanını dikkate alarak bu uygulamayı hakkın kötüye kullanılması yasağı içerisinde değerlendirmiştir. İkinci olarak ise devletler son dönemde yapmış oldukları ikili ve çok taraflı

\footnotetext{
Janig, s. 311.

Foote, s. 8.

10 Schreuer, s. 19.

11 Manuel Casas, "Nationalities of Convenience, Personal Jurisdiction, and Access to InvestorState Dispute Settlement", 2016, 49(1), New York University Journal of International Law and Politics, s. 67.
} 
yatırım anlaşmalarına tâbiiyet planlamasına karşı hükümler koymuşlardır. $\mathrm{Bu}$ bağlamda devletler, bazı anlaşmalarda yatırımcı tanımını daraltırken, diğer bazı anlaşmalarda yatıımcı tanımının daraltılmasına ilave olarak veya bundan bağımsız olarak faydaların reddi (denial of benefits) hükümlerine yer vermektedir. Bununla birlikte gerek hakkın kötüye kullanılması yasağının hakemlerce yeknesak bir şekilde uygulanmaması, gerek yatırımcı tanımı ve faydaların reddi hükümlerinin hakem kararlarında tam bir tutarlılık içerisinde ele alınmaması tâbiiyet planlamasını uluslararası yatırım hukukunun önemli bir sorunu haline getirmiştir.

$\mathrm{Bu}$ çalışma tâbiiyet planlamasının uluslararası yatırım hukuku bakımından doğurduğu sonuçları incelemeyi amaçlamaktadır. İnceleme dört bölüme ayrılacaktır. İlk bölümde tâbiiyetin esas itibariyle şirket ile bir devlet arasındaki hukuki bağı ifade etmesi nedeniyle; ulusal hukuk düzenlerinde ticaret şirketleri ile devlet arasındaki bağın nasıl kurulduğu, bunun için hangi esasların kullanıldığ 1 konusu üzerinde durulacaktır. İkinci bölümde uluslararası hukuk ve özellikle uluslararası yatırım anlaşmalarında ticaret şirketlerinin tâbiiyetinin ele alınış biçimi açıklanacaktır. Üçüncü bölüm tâbiiyet planlaması kavramı ile bu kavram ekseninde şirket tâbiiyetinin hakem kararlarında ele alınış biçimine ayrılacaktır. Dördüncü bölümde ise tâbiiyet planlamasına karşı içtihat ve uluslararası yatırım anlaşmaları yoluyla geliştirilen tepkiler incelenecektir. Sonuç bölümünde ise tâbiiyet planlamasina karşı kullanılabilecek en doğru yöntem konusunda kanaatimiz açılanacaktır.

\section{ULUSAL HUKUK DÜZENLERINDE TICARET ŞİRKETLERININ TÂBIIYYETININ TAYINİ IÇIN KULLANILAN ESASLAR}

Tâbiiyet en genel anlamı ile kişi ve şeyleri devlete bağlayan hukuki ve siyasi bağdır ${ }^{12}$. Tanımda yer verilen kişi kavramı gerçek ve tüzel kişileri, şeyler ise hava ve gemi araçlarını kapsamaktadır ${ }^{13}$. Pek çok ülkede gerçek kişilerin tâbiiyeti vatandaşlık kanunları ile düzenlenmekle birlikte, tüzel kişi ve şeylerin tâbiiyeti konusunu düzenleyen milli hukuk düzenlemelerine genellikle rastlanılmamaktadır ${ }^{14}$. Bu nedenle geçmişte tüzel kişi ve şeylerin

12 Tuğrul Arat, Ticaret Şirketlerinin Tâbiiyeti, Sevinç Matbaası, 1970, s.1; Osman Fazıl Berki, Devletler Hususi Hukuku, Cilt I, Yedinci Bask1; Güzel Sanatlar Matbaası, 1970, s. 15.

13 Berki, s. 15.

14 James Crawford, Brownlie's Principles of Public International Law, Ninth Edition, Oxford Publishing, 2019, s. 513. 
tâbiiyetinin olup olmayacağ doktrinde tartışmalı bir konu olmuştur ${ }^{15}$. Günümüzde ise yabancı şirketlerin yurt içinde sahip olacağı haklar ve tâbi olacağı yükümlülükler gibi ulusal meseleler ile diplomatik koruma gibi uluslararası hukuktan doğan pratik gereksinimler nedeniyle başta ticaret şirketleri olmak üzere tüzel kişi ve şeylerin tâbiiyetinin olduğu baskın görüş olarak kabul edilmektedir ${ }^{16}$. Niteliği gereği, tüzel kişi ve şeylerin devlet ile olan bağ 1 , gerçek kişilere kıyasla farklı bir anlamı ifade etmektedir. Gerçek kişilere mahsus duygusal bağlılık ve sadakat ilişkisi, tüzel kişi ve şeyler bakımından aranmamakta, tüzel kişi ve şeylerin tâbiiyeti hukuki bir statü olarak tecelli etmektedir ${ }^{17}$. Esasen gerçek kişilerin devlet ile olan hukuki ve siyasi bağını ifade etmek için vatandaşlık kavramı, gerçek kişilere ilave olarak tüzel kişi ve şeylerin devlet ile olan bağını tanımlamak için bir üst kavram olan tâbiiyet kavramı kullanılmaktadır ${ }^{18}$. Kanaatimizce de tüzel kişilerin devlet ile olan bağını ifade etmek için vatandaşlık ifadesi yerine üst kavram olan tâbiiyet ifadesinin kullanılması daha doğrudur. Ticaret şirketlerinin tâbiiyetine dair bu incelemede de tâbiiyet kavramı tercih edilecektir.

Şirketlerin tâbiiyetinin tayini konusunda doktrinde kurucuların vatandaşlığ sistemi gibi esaslardan yararlanılabileceği veyahut şirket tâbiiyetinin somut olayın şartları çerçevesinde hâkim tarafından tayin edilebileceği (eklektik sistem) öne sürülmüştür ${ }^{19}$. Hiç şüphesiz, söz konusu esaslardan hangisi veya hangileri kullanılarak şirketlerin tâbiiyetinin belirleneceği konusunda devletlerin mahfuz yetkileri bulunmaktadır ${ }^{20}$. Bununla birlikte uygulamada şirketlerin tâbiiyetinin tayini açısından ekseriyetle kuruluş ve merkez

15 Gülören Tekinalp, Türk Hukukunda Ortaklıkların Vatandașlığı, İstanbul Üniversitesi Hukuk Fakültesi 50. Y1l Armağan1, Cumhuriyet Döneminde Hukuk, Fakülteler Mahallesi, 1973, s. 554; Erdoğan Göger, Türk Tâbiiyet Hukuku, Dördüncü Bası, Sevinç Matbaası 1979, s. 203 ve 208; Jean-Paulin Niboyet, "Şirketlerin Hakikaten Bir Tâbiiyeti Mevcut Mudur?", (Çev: Hicri Fişek), 1952, 9 (3), Ankara Üniversitesi Hukuk Fakültesi Dergisi s. 97-113.

16 Engin Nomer, Türk Vatandaşlık Hukuku, 27. Bask1, Filiz Kitapevi, 2020, s. 45; Gülin Güngör, Tâbiiyet Hukuku, 8. Bas1, Yetkin Yayınları, 2020, s. 245-246; Tekinalp, s. 553; Musa Aygül, Uluslararası Özel Hukukta Sirketlere Uygulanacak Hukukun Tespiti, Seçkin Yayınları, 2007, s. 20; Rona Aybay/Nimet Özbek / Gizem Ersen Perçin, Vatandașlık Hukuku, Siyasal Kitapevi, 2019, s. 281; Vahit Doğan, Türk Vatandaşlık Hukuku, 16 (Tipk1) Bask1, Savaş Yayınevi, 2020, s. 218-219.

17 Doğan, s. 218.

18 Berki, s. 15-16; Doğan, s. 5; Güngör, s. 1;

19 Arat, s. 64; Güngör, s. 247.

20 Berki, s. 129; Güngör, s. 247. 
yeri esasları dikkate alınmakta, istisnai durumlarda ise kontrol sistemine başvurulmaktadır ${ }^{21}$. Kuruluş yeri ve merkez yeri esasları aşağıda daha detaylı olarak ele alınacak olmakla birlikte, konunun tekemmülü açısından diğer esaslara da özet olarak değinilmesinde fayda görülmektedir.

Kurucuların vatandaşlığının esas alınmasını savunan görüş, şirketlerin tâbiiyetinin tespitinde şirketin kurucuları olan gerçek kişilerin vatandaşlığının ölçüt olması gerektiğini ileri sürmüştür. Şirketlerin tâbiiyetini kurucular1 olan gerçek kişilerin vatandaşlığına bağlayan bu görüş, gerçekte şirketlerin tâbiiyetini reddetmektedir. Diğer bir anlatımla, şirket tâbiiyetini kurucuları olan gerçek kişilerin tâbiiyetinden ayrı mütalaa etmeyen bu görüş, örtülü olarak şirketlerin bağımsız bir tâbiiyetinin olmayacağını savunmaktadır. Öte yandan, kurucuların vatandaşlığının esas alınmasını savunan görüş birden fazla ülkenin vatandaşlarının bir araya gelerek kurdukları şirketlerin tâbiiyetini açıklamakta yetersiz kalmaktadır. Şirketlerin tâbiiyetini sermayenin bulunduğu yere bağlayan görüş ise tâbiiyetin tespitinde sermayenin konulduğu ülkenin dikkate alınmasını önermektedir. Sermayenin bulunduğu yer görüşü, günümüzde sıklıkla karşılaşıldığı üzere hisseleri birden fazla ülkede dolaşımda olan şirketlerin tâbiiyetini belirlemede eksik kalmaktadır. Kontrol esası görüşü ise özellikle I. ve II. Dünya Savaşları sırasında tüzel kişilik perdesinin ${ }^{22}$ kaldırılarak düşman devlet veya düşman devlet vatandaşları tarafından kontrol edilen şirketlerin ekonomik faaliyetlerinin önlenmesi ve bu şirketlere yaptırım uygulanması amacıyla ortaya atılmıştır ${ }^{23}$. Bu bağlamda kontrol esası temelde

21 Aygül, s. 21; Arat, s. 64-67; Doğan, s. 219-220; Güngör, s. 247. Söz konusu esaslara getirilen eleştiriler konusunda daha ayrıntılı bilgi için bkz. Arat, s 64-67.

22 Tüzel kişiler, kendilerini oluşturan kişi veya mal topluluklarından ayrı ve bağımsız bir kişiliğe sahiptir. Bu bağlamda tüzel kişilerin borç ve yükümlülüklerinden dolayı kural olarak tüzel kişiyi oluşturan kişi veya mal topluluklarının sorumluluğuna gidilemez. Ancak bazı durumlarda gerçek kişiler, kanun, sözleşme ve uluslararası hukuktan doğan yükümlülüklerden kurtulmak için tüzel kişiler bir araç olarak kullanmaktadır. İşte bu durumun engellenmesi amacıyla bir yöntem olarak "tüzel kişilik perdesinin kaldırılması" teorisi geliştirilmiştir. Böylelikle perde kaldırılarak tüzel kişiyi oluşturan kişi veya mal topluluğuna erişim sağlanmakta ve kanun, sözleşme ve uluslararası hukuktan doğan yükümlülükler bunlara uygulanabilir hale getirilmektedir. Milletlerarası özel hukukta tüzel kişilik perdesinin kaldırılması konusunda geniş bilgi için bkz. Emre Esen, Milletlerarası Özel Hukukta Tüzel Kişilik Perdesinin Kaldırılması, 2. Baskı, Beta Yayınları, 2012.

23 Aygül, s. 29-30; Arghyrios Fatouros, "National Legal Persons In International Law" in Rudolf L. Bindschedler, Thomas Buergenthal, Karl Doehring, Jochen Abr. Frowein, Günther Jaenicke, Herbert Miehsler, Hermann Mosler, Frıtz Münch, Daniel P. O'connell, Karl Josef Partsch, Pierre Pescatore, Henry G. Schermers, Ulrich Scheuner, Hans-Jürgen Schlochauer, Max Sørensen, Helmut Strebel (Eds.), Encyclopedia Of Disputes Installment, Elsevier, 1987, s. 300. 
savaş dönemlerinin ortaya çıkarmış olduğu zaruret nedeniyle, ülke aleyhine faaliyet gösteren şirketlerin düşman karakterlerini ortaya çıkarmak için başvurulan bir sistem olmuştur. Söz konusu sistem savaş sonrası dönemde ise belli bir endüstride yabancı hâkimiyetini önlemek bakımından başta Fransa olmak üzere bazı ülkelerde sınırlı da olsa uygulama alanı bulmuştur ${ }^{24}$. Diğer yandan bu esas, aşağıda inceleneceği üzere uluslararası yatırım anlaşmalarında da kendisine yer bulmuştur. Şirketlerin tâbiiyetinin tayini açısından ortaya atılan eklektik sistem ise tâbiiyetin tayini için ortaya atılan sistemler ve somut olayın özellikleri dikkate alınarak şirketlerin tâbiiyetinin hâkim tarafından tespit edilmesi gerektiğini ileri sürer. Eklektik sistem bu yönüyle tüm sistemlere getirilen eleştirileri bünyesinde toplar. Sistem ayrıca hangi hâkimin hangi olayda, hangi unsura, ne oranda önem atfedeceği konusunda belirsizlikler içermektedir. Bu durum elektik sistemi şirketlerin tâbiiyetinin belirlenmesi açısından güvensiz ve istikrarsız kılmaktadır ${ }^{25}$.

Şirketlerin tâbiiyetinin tespiti bakımından uygulamada başvurulan sistemler konusunda ise ilk olarak kuruluş yeri (incorporation) esasına değinilmelidir. Kuruluş yeri esası şirketin kuruluş işlemlerinin gerçekleştirildiği ve şirketin tüzel kişilik kazandığı yerin aynı zamanda şirketin tâbiiyetini de belirlemesi gerektiğini savunmaktadır ${ }^{26}$. Bu esasın düşünsel temelini; şirketin hukuk dünyasında hayat bulması için belli bir hukuk düzeninin öngördüğü kurallara uygun olarak kurulması gerektiği görüşü oluşturmaktadır ${ }^{27}$. Diğer bir anlatımla, şirket kişiliğini kurulduğu devletin hukukundan almaktadır ${ }^{28}$. Kuruluş yeri esası kurucuların iradesine önem vermesi yanında açık ve basit olması nedeniyle doktrinde destek bulmuştur ${ }^{29}$. Buna mukabil sistem, fazlaca şekilci (biçimsel) olması, şirketin esas faaliyetlerine uzak bir ülkede vergisel avantajlar, minimum sermaye şartı ve belli bir anlaşmanın sağlamış olduğu haklardan yararlanma gibi sırf belli menfaatlerin temini için kurulmasına imkân tanıması nedeniyle de eleştirilmektedir ${ }^{30}$. Daha açık bir ifade ile kuruluş yeri esası şirketin gerçek bağının (genuine link) bulunmadığı bir devletin

\footnotetext{
Arat, s. 95-96.

25 Arat, s. 92.

26 Erdoğan Moroğlu, “Anonim Ortaklıkların Tabiiyeti ve Tanınması”, 2011, 22(2), Milletlerarası Hukuk ve Milletlerarası Özel Hukuk Bülteni, s. 414; Güngör, s. 247.

27 Arat, s. 71.

28 Arat, s. 68; Tekinalp, s.559.

29 Arat, s. 68; Doğan s, 220; Moroğlu, s. 416.

30 Aygül, s. 22; Arat, s. 73-74; Doğan, s. 220.
} 
tâbiiyetini kazanmasına olanak sağlamaktadır. Tüm eleştirilere rağmen kuruluş yeri sistemi günümüzde Anglo-Amerikan hukuk sistemlerinde kullanılmaktadır ${ }^{31}$. Bu bağlamda tarihsel süreç içerisinde ABD ve İngiltere'ye ilave olarak Arjantin, Japonya ve Mısır gibi ülkeler kuruluş yeri sistemi çerçevesinde şirket tâbiiyetini tayin etmişlerdir ${ }^{32}$. Öte yandan Kıta Avrupası hukuk sistemi içerisinde yer almakla birlikte Hollanda ve İsviçre gibi ülkeler zaman içerisinde idare merkezi esasından kuruluş yeri sistemine geçmişlerdir.

Uygulamada şirketlerin tâbiiyetini tayin açısından kullanılan ikinci sistem merkez yeri (seat) esasıdır. Merkez yeri esasına göre şirketin tâbiiyet kazanması için şirketin hem ilgili devletin kanunlarına uygun olarak kurulması, diğer bir anlatımla tüzel kişilik kazanması, hem de şirket merkezinin aynı devlette olması gereklidir ${ }^{33}$. Merkez yerinin tespitinin kolay olması yanında devamlılık arz etmesi nedeniyle, şirket tâbiiyetinin tayinini kolaylaştıracağ öne sürülmüştür ${ }^{34}$. Bununla birlikte merkez yeri konusunda doktrin ve içtihatta farklı görüşlerin ortaya çıkması merkez yeri tayininin sanıldığı kadar kolay olmadığını ortaya çıkarmıştır. Nitekim şirketler bakımından idare merkezi ve işletme merkezi şeklinde iki merkezden söz edilebilir. Bunlardan idare merkezi şirketin idare edildiği, organlarının toplandığı, şirketin faaliyetlerine ilişkin sözleşmelerin yapıldığı ve kararlarının alındığı yeri ifade eder ${ }^{35}$. İşletme merkezi ise şirketin işletme veya işletmelerinin bulunduğu yer veya yerleri belirtmek için kullanılır. Geçmişte şirketlerin tâbiiyetinin tayini açısından işletme merkezinin esas alınması gerektiği ileri sürülmüş olsa da bir şirketin birden fazla işletme merkezinin olabilmesi ve dolayısıyla birden fazla tâbiiyetin ortaya çıkaracağı sakıncalar nedeniyle günümüzde şirketin merkez yeri olarak idare merkezinin alınması gerektiği konusunda fikir birliğinin olduğu ifade edilebilir ${ }^{36}$. Şirketin idare merkezi konusunda da şirket ana statüsünde (esas sözleşmesinde) gösterilen merkez (statutory seat) ve fiili idare merkezi (real seat, siege social reel) şeklinde ikili bir ayrıma gidilebilir. Kural olarak şirket ana statüsünde gösterilen merkez, fiili idare merkezine karine teşkil eder. Ancak şirket fiilen ana statüde gösterilen, yani tescil edildiği ülkeden başka bir ülkeden de yönetilebilir. Şirketin fiilen idare edildiği merkezin, ana statüde

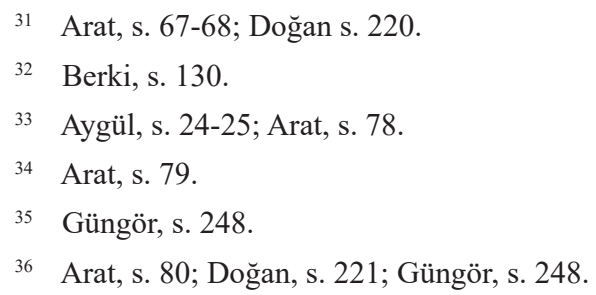


idare merkezi olarak gösterilen ülkeden farklı bir ülkede olması durumunda ise, şirketin tâbiiyeti açısından fiili idare merkezinin bulunduğu ülkenin esas alınması gerektiği kabul edilmektedir ${ }^{37}$. Merkez yeri sistemi daha çok KıtaAvrupası hukuk sistemleri tarafindan benimsenmiştir. Nitekim Fransız ve Alman mahkemelerin oldukça eski içtihatlarında şirketlerin tâbiiyetini merkez yeri esasına uygun olarak tespit ettikleri görülmektedir ${ }^{38}$. Bu ülkelere ilave olarak Avusturya, Belçika, İtalya ve Yunanistan gibi Kıta-Avrupası hukuk sistemine dahil olan ülkeler geleneksel olarak şirketlerin tâbiiyeti konusunda idare merkezini esas almışlardır ${ }^{39}$.

Türk hukukunda ise tüzel kişilerin tâbiiyetini konu edinen genel bir düzenleme bulunmamaktadır. Bununla birlikte Türk Ticaret Kanunu (TTK) ile çeşitli özel kanunlardan hareketle Türk hukukunda ticaret şirketlerinin

37 Aygül, s. 26; Doğan, s. 221; Tekinalp, s. 560.

38 Söz konusu karar örnekleri için bkz. Arat, s. 78, dipnot 56.

39 Berki, s. 130; Öte yandan belirtmek gerekir ki; Avrupa Birliği Adalet Divanı'nın (ABAD) 1999 yılında karara bağladığ 1 Centros davası ile müteakip yıllarda ele aldığı Überseering ve Inspire Art davalarında vermiş olduğu kararlar şirketlerin tâbiiyetinin tayininde esas alınacak sistem konusunda Kıta-Avrupası hukuku üzerinde önemli etkiler doğurmuştur. Söz konusu kararlar esas itibariyle yerleşme serbestîsi, şirketlerin tanınması ve şirket statüsüne ilişkindir. Ancak şirketlerin tanınması ve statüsü ile şirketlerin tâbiiyetlerinin tayini açısından aynı esasların (kuruluş yeri ve merkez yeri esasları) kullanılması, kararların şirketlerin tâbiiyetinin tayini açısından sonuç doğurmasına neden olmuştur. ABAD bahse konu kararlar ile AB'ye üye ülkelerde kurulmuş olan șirketlerin yerleșme serbestisi kapsamında esas faaliyetlerini başka bir $\mathrm{AB}$ üyesi ülkede yürütebileceğine karar vermiștir. Başka bir anlatımla, $\mathrm{ABAD}$ anılan kararlar ile $\mathrm{AB}$ üyesi bir ülkede kurulmuş olan bir şirketin tabi olduğu hukuku değiştirmeden idare merkezini ve faaliyetlerini başka bir AB üyesi ülkeye taşıyabilmesinin önünü açmıştır. Bu durum şirket kurumu ve şirket statüsünün belirlenmesi konusunda ABAD'ın kuruluş yeri esasına öncelik verdiğini göstermektedir. Bahse konu kararlar sonrasında ise şirket kurulumu ve faaliyetlerin devamı konusunda çeşitli avantajlar tanıyan ülkelere bir tür şirket göçü başlamıştır. Nitekim merkez yerleri Almanya, Fransa, Hollanda ve Norveç olmakla birlikte, yeni kurulan şirketler kuruluş yeri olarak o dönem $\mathrm{AB}$ üyesi olan Birleșik Krallık'ı tercih etmișlerdir (Bu durumu gösteren ampirik bir çalışma için bkz. Marco Becht/ Colin Mayer/ Hannes F. Wagner Where Do Firms Incorporate? Deregulation and the Cost of Entry, European Corporate Governance Institute, Working Paper 70/2006, 2007). Şirket göçünün önlenmesi ve yeni şirket kurulumu konusunda rekabetçiliğinin sağlanması amaçları çerçevesinde İrlanda ve Belçika'nın yanı sıra 2008 yılına kadar merkez yeri esasını istikrarlı bir şekilde uygulayan Almanya'da dahi limited (Gesellschaft mit beschränkter Haftung "GmbH") ve anonim (Aktiengesellschaft " $A G$ ") şirketlerin tâbiiyeti bakımından kuruluş yerini benimseyen bir takım değişikliklerin (Modernisierung des GmbH-Rechts und zur Bekämpfung von Missbräuchen "MoMiG") yapılması zorunluluğu doğmuștur. (Bu konuda detaylı bir çalıșma için bkz. Marie Louise Seelig/ Anke Sessler/ Hartmut Paulsen, Impact of MoMiG on "Sitztheorie"/"Gründungsthe orie" - Consequences for German BITs, in The Determination of the Nationality of Investors under Investment Protection Treaties, Institute of Economic Law (Transnational Economic Law Research Center), 2011, s. 25-36). 
tâbiiyeti bakımından benimsenen sistem konusunda bir sonuca varmak mümkündür. Bu bağlamda Doğal Gaz Piyasası Kanunu'nda “yerli ve yabancl şirket" ifadesine yer verilmiştir ${ }^{40}$. Türk şirketlerini tanımlamak bakımından Maden Kanunu ile Jeotermal Kaynaklar ve Doğal Kaynaklar Kanunu'nda "Türkiye Cumhuriyeti Kanunlarına göre kurulmuş" "4l, Sigortac1lık Kanunu'nda "Türkiye'de kurulmuş"2, Bankac1lll1k Kanunu'nda ise "Türkiye'de kurulu"43 ifadeleri kullanılmıştır. Özel kanunlarda geçen bu ifadeler kanun koyucunun bahse konu kanunlara konu iş ve işlemler açısından tâbiiyet fikrinden hareket ettiğini göstermektedir. Bununla birlikte söz konusu hükümlerin lafızlarına bakıldığında kanun koyucunun Türk tâbiiyetinde bulunan şirketleri tayin açısından kuruluş yeri esasını benimsendiği izlenimi doğabilir. Oysa, TTK hükümleri yakından incelendiğinde Türk hukukunda ticaret şirketlerinin tâbiiyeti bakımından kabul edilen sistemin gerçekte merkez yeri esası olduğu anlaşılmaktadır ${ }^{44}$. Bu konuda öncelikle TTK m.232, 355 ve 588'de uyarınca ticaret şirketlerinin tüzel kişilik kazanmaları için bunların tescil edilmelerinin şart koşulduğu vurgulanmalıdır. Diğer bir deyişle tescil şirketin kurulumu, dolayısıyla da tâbiiyet kazanmasının ön koşuludur. Ancak Türk hukukunda şirketlerin tâbiiyetini tayin bakımından tescil yanında tescilin yapıldığ yerinde dikkate alınması icap eder. Tescilin nereye yapılacağı konusunda ise TTK m.213, 339 ve 576 hükümleri merkez yerinin şirket sözleşmesi/ şirket esas sözleşmesine yazılmasını, TTK m.215, 354 ve 587 ise sözleşmenin şirket merkezinin bulunduğu yer ticaret siciline tescilinin yapılmasını öngörmektedir ${ }^{45}$. Yukarıda açıklandığı üzere, merkez konusunda şirketin fiili/gerçek idare merkezinin esas alınması gereklidir ${ }^{46}$. Daha açık bir ifade

40 Doğal Gaz Piyasası Kanunu ((Elektrik Piyasası Kanununda Değişiklik Yapılması ve Doğal Gaz Piyasas1 Hakkında Kanun) (RG: 5.02.1985 - 18785), m. 4.

${ }_{41}$ Maden Kanunu (RG: 15.06.1985 - 18785), m. 6; Jeotermal Kaynaklar ve Doğal Kaynaklar Kanunu (RG: 13.6/.2007 - 26551), m.4.

42 Sigortac1l1k Kanunu (RG: 14.6.2007 - 26552), m. 2.

43 Bankacılık Kanunu (RG: 1.11.2005 - 25983 (Mük.)), m. 2.

44 Arat, s. 106-107; Doğan, s. 223; Güngör, s. 257; Kırca İ,/ Şehirali Çelik F./ Manavgat Ç., Anonim Şirketler Hukuku, C.1, 2013, s. 80.

45 Güngör, s. 257

46 Yukarıda yer verilen açıklamalara ilave olarak merkezin ticaret şirketlerinin tabiiyetini tayin bakımından kilit bir role haiz olduğunu TTK'nın diğer hükümlerinden de çıkarmak mümkündür. Nitekim anonim şirketlere ilişkin TTK m.421/2(b) hükmü şirket merkezinin yurt dışına taşınmasına ilişkin kararların oybirliği ile alınmasını öngörmektedir. Yine TTK'nın çeşitli hükümlerinde genel kurulun toplantıya çağrılması, borca batık şirketin iflasını talep etme ve denetim gibi şirketi ilgilendiren önemli hususlar hakkında şirket 
ile ancak filli idare merkezi Türkiye'de olan şirketler ticaret siciline tescil edilebilecektir. TTK m.32/2 gereğincede bu husus sicil müdürü tarafından re'sen nazara alınacak ve yurt dişında merkez tesis etmekle birlikte Türkiye'de farazi (fiktif) bir merkez tesis edilerek yapılacak başvurular sicil müdürünce reddedilecektir ${ }^{47}$. Hülasa bir şirketin Türk hukuku bakımından Türk şirketi olarak kabul edilmesi için şirket merkezinin Türkiye'de tesis edilmesi ve bu merkezin bulunduğu yer siciline tescil edilmesi gerekmektedir ${ }^{48}$.

\section{ULUSLARARASI HUKUK ve ÖZELLİKLE ULUSLARARASI YATIRIM ANLAŞMALARINDA TICARET ŞİRKETLERININ TÂBIIYYETININ ELE ALINIŞ BICÇIMİ}

Uluslararası hukuk gerçek kişiler gibi tüzel kişiler bakımından da tâbiiyet bağının nasıl kurulacağını ilke olarak ulusal hukuk düzenlerine bırakmıştır ${ }^{49}$. Bu manada şirketler de dâhil olmak üzere tüzel kişiler ile devlet arasındaki tâbiiyet bağının nasıl kurulacağı ulusal hukuka ait bir konudur ve kural olarak ulusal hukuk düzenleri tarafindan tayin edilen tâbiiyet bağ hukuk tarafindan tanınır ${ }^{50}$. Buna mukabil, ulusal hukuk tarafindan kurulan tâbiiyet bağına dayalı olarak uluslararası hukukun tüzel kişilere sağladığ 1 korumadan yararlanmanın koşullarını belirlemek uluslararası hukuka ait bir meseledir ${ }^{51}$. Genel uluslararası hukuk bakımından bu mesele devletler tarafindan şirketlere sağlanan diplomatik koruma konusu ile yakından ilgilidir. Zira yirminci yüzyılın ikinci yarısına kadar, gerçek kişiler ve şirketler de dâhil tüzel kişilere verilen zararı içeren her türlü uluslararası anlaşmazlığın

merkezinin bulunduğu yer asliye ticaret mahkemesine başvurulmasının öngörülmesi de; merkez yerinin önemini bir kez daha ortaya koymaktadır. Şirket açısından hayati önemi haiz söz meseleler hakkında gerçek/fiili idare merkezinin bulunduğu yer mahkemesinin karar alması işin niteliği gereğidir.

47 Arat, s. 107-108; aynı yönde görüş için bkz. Aygül, s. 35; Doğan, s. 223; Kırca/ Şehirali Çelik/ Manavgat, s. 80.

48 Arat, s. 106-107; Kırca/ Şehirali Çelik/ Manavgat, s. 80-81.

49 Barcelona Traction, Light \& Power Co., Ltd. (New Application: 1962) (Belg. v. Spain), Judgment,1970 I.C.J. Rep. 3, para 38; Draft Articles on Diplomatic Protection with Commentaries, Int'l Law Comm'n, U.N. Doc. A/61/10, 2006, s. 37; Nationality Decrees Issued in Tunis and Morocco, (French Zone), Advisory Opinion, PCIJ Reports, Series B, No. 4, s. 24.

50 Berk Demirkol, "Yatırım Tahkiminde Paravan Şirketlerin Yol Açtı̆̆ Yetki Sorunları”, 2012, 28 (3), Banka ve Ticaret Hukuku Dergisi, s. 308.

51 Demirkol, s. 309. 
çözümünün diplomatik koruma yoluyla sağlandığını hatırlamak gerekir ${ }^{52}$. Devletler tarafından tâbiiyetinde bulunan kişiler adına uluslararası uyuşmazlık başlatmak da diplomatik korumanın kapsamına giren bir konu olarak kabul edilmektedir ${ }^{53}$. Yirminci yüzyılın ikinci yarısından sonra uluslararası yatırım hukuku da dâhil olmak üzere pek çok alanda gerçek ve tüzel kişiler, uluslararası bir süje olarak tâbiiyetinde oldukları devletten bağımsız olarak uluslararası uyuşmazlık çözüm mekanizmalarına başvuru imkânına kavuşmuş olsalar ve bu manada diplomatik korumanın önemi görece azalmış olsa da; etkisi tümüyle kaybolmamıştır ${ }^{54}$. Bu nedenle öncelikle diplomatik koruma kapsamında devlet ile ticaret şirketleri arasındaki tâbiiyet ilişkisi genel hatları ile ele alınmalıdır.

Devletler tarafından şirketlere sağlanacak diplomatik koruma konusunda genel uluslararası hukuk, şirket ile devlet arasındaki şekli tâbiiyet ilişkisini yeterli saymaktadır. Nitekim Uluslararası Hukuk Komisyonu (UHK) tarafindan 2006 yllında oluşturulan Diplomatik Korumaya İlişkin Taslak Maddeler Çalışması m.9 şu şekildedir: "Bir şirket üzerinde diplomatik korunma sağlanmasına ilişkin olarak, vatandaşlık devleti şirketin onun hukukuna göre kurulduğu devlet anlamına gelir. Fakat şirket diğer devlet veya devletlerin vatandaşlart tarafindan kontrol ediliyorsa ve kuruluş devletinde esasl bir iş faaliyeti yoksa ve yönetim merkezi ve şirketin finansal kontrolünün her ikisi de bu diğer devlette yer allyorsa, bu devlet vatandaşlik devleti olarak kabul edilir. "'55 Söz konusu hüküm devletlerin ticaret şirketlerine sağladığ diplomatik koruma mevzusunda öncelikli olarak kuruluş yeri esasının kullanılacağını öngörmektedir ${ }^{56}$. Bunun ötesinde kuruluş yeri devleti dışında

52 Anthony C. Sinclair, "ICSID's Nationality Requirements", 2008, 23(1), ICSID Review Foreign Investment Law Journal, s. 58; Casas, s. 91.

53 Casas, s. 91.

54 Sinclair, s. 58; Yasin Söyler, "Barcelona Traction Davası ve Uluslararası Hukuka Etkisi”, 2015, 19(3), Ankara Hacı Bayram Veli Üniversitesi Hukuk Fakültesi Dergisi, s. 212.

55 Bu metin Gökhan Albayrak tarafından yapılan "Diplomatik Koruma Hakkında Taslak Maddeler (Draft Articles On Diplomatic Protection)" çevirisinden aynen alınmıştır. Çevirinin tümü için bkz. Gökhan Albayrak, "Diplomatik Koruma Hakkında Taslak Maddeler (Draft Articles on Diplomatic Protection)", Y11 4, 2019/2, YBHD, s. 501-507.

56 UHK'nın Diplomatik Korumaya İlişkin Taslak Maddeler Çalışması m.9'un dayanağını büyük ölçüde Uluslararası Adalet Divanı'nın (UAD) Barcelona Traction davasında verdiği karar oluşturur. Davaya konu olan olayda İspanya, Kanada kanunlarına göre kurulmuş, İspanya'da faaliyet gösteren ve hissedarlarının büyük bir kısmının Belçika vatandaşı olan Barcelona Traction şirketine el koymuştur. Bunun üzerine, Belçika devleti hissedarlar adına diplomatik koruma hakkını kullanarak konuyu UAD'ye taşımıştır. İspanya Barcelona 
başka bir devletin diplomatik koruma sağlaması istisnai nitelikte ve belli şartlar dâhilinde mümkün olacaktır. Bu açıdan şirketin başka devlet vatandaşları tarafindan kontrol edilmesi yeterli olmayacak, ilave olarak kuruluş devletinde esaslı bir iş faaliyetinin olmaması ve yönetim merkezi ile şirketin finansal kontrolünün her ikisinin de diğer devlette yer alması gerekecektir ${ }^{57}$.

Genel uluslararası hukukun ötesinde devletlerin aralarında yapacakları anlaşmalarla şirketlerin tâbiiyetinin belirlenmesi konusunda özel kural (lex specialis) ihdas edebilecekleri şüphesizdir ${ }^{58}$. Uluslararası yatırım hukuku bu alanların başında gelmektedir. Uluslararası yatırım hukuku bağlamında şirketlerin tâbiiyetinin tayini açısından evvela Devletler ve Diğer Devletlerin Vatandaşları Arasındaki Yatırım Uyuşmazlıklarının Çözümlenmesi Hakkında Konvansiyon'a (ICSID Konvansiyonu) bakmak yerinde olacaktır. Zira anılan Konvansiyon 1 Haziran 2021 tarihi itibariyle 155 devletin taraf olduğu çok taraflı bir anlaşma niteliğindedir ${ }^{59}$. Ayrıca uluslararası yatırım uyuşmazlıklarının büyük kısmı Konvansiyon ile kurulan Uluslararası Yatıım Uyuşmazlıkları Çözüm Merkezi’ne (Merkez) bağlı olarak görev yapan

Traction şirketinin kuruluş yeri olan Kanada'nın tâbiiyetinde olduğunu öne sürerek Belçika'nın yapmış olduğu başvuruya itiraz etmiştir. UAD ise kuruluş yeri ülkesi olarak diplomatik koruma hakkının Kanada'ya ait olduğuna karar vermiştir. Divan Barcelona Traction şirketinin Kanada tâbiiyetinde bulunduğu göstermek bakımından; şirketin bu ülkede kurulmasına ilave olarak bir takım başka hususlara da vurgu yapmıştır. Divan bu bağlamda şirketin hesaplarının tutulduğu, toplantılarının yapıldığ 1 ve vergi listelerinde bulunduğu yerin Kanada olduğuna ve bu irtibatların istikrarlı bir şekilde devam etmiş olmasına dikkat çekmiştir. Doktrinde bazı yazarlarca, bu vurgular nedeniyle Divan'ın tâbiiyet açısından aslında tüzel kişi ile devlet arasına gerçek bağı (genuie link) arandığ ifade edilmiştir. Kanaatimizce Divan tüzel kişi tâbiiyetinin tayininde esas itibariyle kuruluş yeri esasını kullanmıștır. Divanın ilave olarak yaptığı vurgular ise, esas itibariyle Barcelona Traction'ın Kanada tâbiiyetinde olduğunu güçlendirmek için kullandığı ilave argümanlardır. Nitekim Divan'ın kendisi, Nottebohm davasına atıf yaparak gerçek bağ kriterinin şirketlerin tâbiiyetinin tayini açısından kullanılmayacağını açıklamıştır. Bkz. Barcelona Traction, Light \& Power Co., Ltd. (New Application: 1962) (Belg. v. Spain), Judgment,1970 I.C.J. Rep. 3, para 70-71; Ayrıca Barcelona Traction davasının uluslararası hukuk bakımından doğurduğu sonuçları ele alan ayrıntılı bir çalışma için bkz. Söyler, s. 207-247.

57 Draft Articles on Diplomatic Protection with Commentaries, s. 38.

58 Casas, s. 90.

59 ICSID Convention, <https://icsid.worldbank.org/resources/rules-and-regulations/ convention/overview> Erişim Tarihi 1 Haziran 2021; Türkiye ICSID Sözleşmesini 1988 yılında onaylayarak (RG: 6.12.1988 - 19830) iç hukukunun bir parçası haline getirmiştir. ICSID tahkim mekanizmasını Türkiye açısından değerlendiren çalışmalar için bkz. Bilgin Tiryakioğlu, "Yatırımlar ve Uluslararası Tahkim Arasındaki İlişki", 2007, 1(2), Uluslararası Ekonomi ve Dış Ticaret Politikaları, s. 169-184. Rifat Erten, "ICSID Tahkimi”, 1998, 19(4), Banka ve Ticaret Hukuku Dergisi, s. 207-230. 
hakemler eliyle çözümlenmektedir ${ }^{60}$.

Merkezin kişi bakımından yargılama yetkisini (personal jurisdiction, jurisdiction ratione personae) belirleyen ICSID Konvansiyonu m. 25 (2) (b) uyarınca, anlaşmazlığa taraf devlet dışında bir âkit devletin tâbiiyetinde bulunan tüzel kişiler ve tarafların anlaşması koşuluyla anlaşmazlığa taraf devlet tâbiiyetinde olmakla birlikte yabancı kontrolü nedeniyle diğer bir âkit devlet tâbiiyetinde bulunan tüzel kişiler ICSID tahkimine başvurabileceklerdir ${ }^{61}$. Söz konusu hüküm iki kategori altında sınıflanabilecek yatırımcılar bakımından Merkez'in yarg1 yetkisine sahip olduğunu öngörmektedir. Bunlardan ilki anlaşmazlığa taraf devlet dışında bir âkit devletin tâbiiyetinde olan yatırımcılardır. Bu bağlamda yatırımcının, yatırım tahkimine başvurması için anlaşmazlığa taraf devlet dışındaki başka bir âkit devlet tâbiiyetinde olduğunu şeklen göstermesi yeterli olacaktır. İkinci kategoride yer alan yatırımcılar ise şekli olarak anlaşmazlık yaşayan devletin tâbiiyetinde olmakla birlikte, yabanc1 kontrolü nedeniyle diğer bir devlet tâbiiyetindeymiş gibi muamele gören tüzel kişilerdir ${ }^{62}$. Örneğin $\mathrm{X}$ şirketi, A devletinin kanunlarına uygun olarak kurulmuş ve şekli olarak A devletinin tâbiiyetinde gözükmekle birlikte, B devletinin tâbiiyetinde bulunan gerçek veya tüzel kişilerin kontrolü altında olabilir. A devleti yabancı kontrolü nedeniyle $\mathrm{X}$ şirketinin $\mathrm{B}$ devletinin tâbiiyetindeymiş gibi muamele edeceğini (iç hukuk düzenlemesiyle veya uluslararası yatırım anlaşmasıyla) kabul etmiş ise, ICSID Konvansiyonu bakımından X şirketi A devleti aleyhine tahkim sürecini başlatabilecektir. Bu anlamda ikinci kategoride yer alan şirketlerin tâbiiyetinin belirlenmesi, şekli değerlendirmenin ötesinde kontrolün var olup olmadığının tespitine yönelik esasa dair bir incelemeyi de gerekli kılmaktadır. Bununla birlikte belirtmek

${ }^{60}$ Nitekim Birleşmiş Milletler Ticaret ve Kalkınma Konferansı (UCTAD) verilerine göre 30 Haziran 2021 tarihi itibariyle ortaya çıkan 1104 yatırımcı- ev sahibi devlet uyuşmazlığının 685 'i ICSID'de görülmüştür. Konuyla ilgili olarak bkz. Investment Dispute Settlement Navigator, <https://investmentpolicy.unctad.org/investment-dispute-settlement> Erişim Tarihi 30 Haziran 2021.

${ }_{61}$ ICSID Konvansiyonu m. 25(2)(b) hükmünün İngilizce orijinal ifadesi şu şekildedir: "(2) "National of another Contracting State" means: ...(b) any juridical person which had the nationality of a Contracting State other than the State party to the dispute on the date on which the parties consented to submit such dispute to conciliation or arbitration and any juridical person which had the nationality of the Contracting State party to the dispute on that date and which, because of foreign control, the parties have agreed should be treated as a national of another Contracting State for the purposes of this Convention."

62 İlyas Gölcüklü, "ICSID Tahkiminde Yetkiden Kaynaklanan Bazı Sorunlar”, 2018, 38(2), Milletlerarası Hukuk ve Milletlerarası Özel Hukuk Bülteni, s. 298; Erten, s. 217; Ziya Akınc1, Milletlerarası Tahkim, 5. Baskı, Vedat Kitapçı1ık, 2020, s. 59. 
gerekir ki; Merkez'in m.25 (2)(b) kapsamında yabancı kontrolünde olan iç şirketler açısından da yargılama yetkisine sahip olması istisnai niteliktedir ve ancak bu istisnai koşullar altında kontrol testi uygulama alanı bulacaktır ${ }^{63}$. Daha açık bir ifade ile Merkez'in yargı yetkisine sahip olduğu ilk kategoride yer alan yatırımcılar bakımından kontrol şartı aranmayacaktır ${ }^{64}$. Merkez'in yarg1 yetkisi bakımından asıl olan ilk kategoride yer alan yatırımcılardır ve bu yatırımcıların anlaşmazlık tarafı olan devletin dışındaki bir âkit devletin tâbiiyetinde olması yeterlidir.

Öte yandan, ICSID Konvansiyonu m.25(2)(b) Merkez'in kişi bakımından yarg1 yetkisinin âkit devlet tâbiiyetine bulunan tüzel kişiler bakımından geçerli olacağını belirtmekle birlikte, tüzel kişi tâbiiyetinin nasıl tayin edileceğini açıklamamıştır ${ }^{65}$. Esasen ICSID Konvansiyonu m.25 (2)(b) ICSID tahkimi açısından tüzel kişilerin tâbiiyeti kavramının dış sınırını çizmektedir ${ }^{66} . \mathrm{Bu}$ sinır ise ICSID Konvansiyonu m.25 (2)(b)'de yer verilen istisna (yabanc1 kontrolü altında bulunan iç şirketler) dışında, şekli bir sınırlama (anlaşmazlık tarafi devlet dışındaki âkit devlet tâbiiyetinde olma) olarak kabul edilmiştir. $\mathrm{Bu}$ şekli sınır içerisinde ${ }^{67}$ yatırım tahkimine başvurabilecek yatırımcılar ikili yatırım anlaşmaları ile tanımlanmaktadır ${ }^{68}$. Bu halde ICSID tahkimine başvurabilmek için yatırımcının hem ICSID Konvansiyonu m.25 (2)(b)'de öngörülen koşulları hem de ikili yatırım anlaşmasında yer verilen yatırımcı tanımını karşılaması gerekir ${ }^{69}$.

İkili yatırım anlaşmaları ise çoğu kez kuruluş yeri, merkez yeri ve kontrol

63 Akınc1, s. 59; Casas, s. 83; CMS Gas Transmission Co. v. Argentine Republic, ICSID Case No. ARB/01/8, Decision of the Tribunal on Objections to Jurisdiction, 17 July 2003, para 58.

${ }^{64}$ Tokios Tokelés v. Ukraine, ICSID Case No. ARB/02/18, Decision on Jurisdiction, 29 April 2004, para 46.

${ }^{65}$ Gölçüklü, s. 302; Sinclair, s. 64; Tokios Tokelés v. Ukraine, para 24.

66 Sinclair, s. 87; The Rompetrol Group N.V.v. Romania, ICSID Case No. ARB/06/3, Decision on the Respondent's Preliminary Objections on Jurisdiction and Admissibility, 18 April 2008, para. 80 .

67 Burada bahse konu şekli sınırlama ICSID Konvansiyonu bakımından geçerli olup, devlet mahkemeleri veya başka tahkim merkezlerinin yargılama yetkisi bakımından uygulanabilir değildir.

68 Sinclair, s. 64; Christoph H. Schreuer/ Loretta Malintoppi/ August Reinisch/ Anthony Sinclair, A Commentary on the Convention on the Settlement of Investment Disputes between States and Nationals of Other States, Second Edition, 2009, s. 286.

69 Casas, s. 85-86; KT Asia Investment Group BV v Kazakhstan, ICSID Case No ARB/09/8, IIC 615, Award, 2013, para 96; Orascom TMT Investments S.à r.l. v. People's Democratic Republic of Algeria, ICSID Case No. ARB/12/35, Final Award, 2017, para 257. 
esasları temelinde yatırımcıları tanımlamaktadır ${ }^{70}$. İç hukuk düzenlemelerine paralel olarak Anglo-Amerikan hukuk sisteminde yer alan ülkelerin taraf oldukları anlaşmalarda daha çok kuruluş yeri esasına yer verildiği, Almanya, Fransa, İspanya ve İtalya gibi Kita Avrupası hukuk sisteminde yer alan ülkelerin taraf oldukları anlaşmalarda ise merkez yeri esasının kullanıldığ 1 görülmektedir ${ }^{71}$. Bu bağlamda örneğin yatırım konularını da içine alan ve 1 Temmuz 2020 tarihinde yürürlüğe konulan Amerika Birleșik Devletleri (ABD), Meksika ve Kanada Anlaşması'nda (USMCA) şirketleri de kapsayacak şekilde "teşebbüs" kavramı kuruluş yeri esası temelinde tanımlanmıştır ${ }^{72}$. Buna karşılık Almanya ile Libya arasında 2010 yılında yürürlüğe konulan yatırım anlaşmasında şirketleri de kapsayacak şekilde tüzel kişi kavramı, merkez yeri esası dikkate alınarak tanımlanmıştır ${ }^{73}$.

Ancak hemen belirtmek gerekir ki; bu esaslardan kuruluş yeri esası daha yaygın olarak kullanılmakta iken, merkez yeri esası daha az sayıda anlaşmada yer bulmaktadır. Kontrol esası ise çoğunlukla diğer iki esasa ilave olarak yatırım anlaşmasından yararlanacak yatırımcı tanımını genişletmek üzere istisnai olarak kullanılmaktadır ${ }^{74}$. Yine belirtmek gerekir ki; uygulamada yatırım anlaşmalarının bir kısmı tek bir esası, bazısı bu esasları birbirine alternatif olarak, diğer bir kısmı ise üç esasın farklı kombinasyonlarını kullanmaktadır ${ }^{75}$. Bu bağlamda örneğin Hollanda ve Çin Halk Cumhuriyeti (ÇHC) arasında akdedilen yatırım anlaşmasında; şirketlerin tâbiiyeti konusunda âkit tarafların iç hukuklarına atıf yapıldığı ve şirketler de dahil olmak üzere anlaşma tarafı ülkelerin yasalarına göre kurulan ve merkezleri bu

70 Fatouros, s. 300;

71 Markus Perkams, "The Definition of Nationality of Investors in. International Investment Agreement (IIAs) - Taking Stock of the. Criteria Used in Modern Investment Law" in The Determination of the Nationality of Investors under Investment Protection Treaties, Institute of Economic Law (Transnational Economic Law Research Center), 2011, s. 14-15.

72 Agreement between the United States of America, the United Mexican States, and Canada, Article 1.5; <https://ustr.gov/sites/default/files/files/agreements/FTA/USMCA/Text/01Initial-Provisions-and-General-Definitions.pdf> Erişim Tarihi 28 Mayıs 2021.

73 Agreement between the Federal Republic of Germany and the Socialist People's Libyan Arab Jamahiriya concerning the Encouragement and Reciprocal Protection of Investments, $<$ https://investmentpolicy.unctad.org/international-investment-agreements/treatyfiles/3126/download> Erişim Tarihi 30 Haziran 2021.

74 UNCTAD, World Investment Report Investor Nationality: Policy Challenges, 2016, s. 173174.

75 Fatouros, s. 300; Perkams, s. 13. 
ülkelerde olan tüzel kişilerin yatırımcı olarak tanımlandığı görülmektedir ${ }^{76}$. Türkiye ile Fransa arasında akdedilen Yatırımların Karşılıklı Teşviki ve Korunması (YKTK) Anlaşması'nda ise merkez yeri esasına ilave olarak kontrol esasının uygulama alanı bulacağı benimsenmiştir. Nitekim Anlaşmanın tanımlar başlıklı birinci maddesinde "bir Akit Tarafin ülkesinde bu Akit Tarafin mevzuatına uygun olarak kurulmuş bulunan ve yönetim merkezi veya etkin iktisadi faaliyetleri o Akit Tarafin ülkesinde bulunan şirketleri”n yanı sira "Merkezi üçüncü bir ülkede bulunan ve bir Akit Taraf yatırımcıları tarafindan doğrudan veya dolayl olarak yönetilen bir şirket"in de Anlaşma ile sağlanan korumadan yararlanacağı açıklanmıştır ${ }^{77}$. Öte yandan; devletler imzaladıkları her anlaşmada aynı esası kullanmamaktadır. Diğer bir anlatımla bir devlet bir anlaşmada bir esası temel alırken, başka bir anlaşmada diğer bir esası veya bu esasların bir kombinasyonu kullanabilmektedir. Örneğin Türkiye ABD ile akdettiği yatırım anlaşmasında ${ }^{78}$ kuruluş yeri esasını kullanmışken, İspanya ile yaptığ 1 yatırım anlaşmasında ${ }^{79}$ merkez yeri esasını benimsemiştir. $\mathrm{Bu}$ durum yalnızca Türkiye'ye özgü olmayıp Almanya ve İtalya gibi pek çok ülke bakımından da geçerlidir ${ }^{80}$.

Ticaret şirketlerinin tâbiiyetinin tayini açısından uygulamaya bakıldığında ise, hakem kararlarında bu konunun daha çok tâbiiyet planlaması uygulaması etrafında tartışıldığı görülmektedir. Bu tartışma özellikle, ev sahibi devlet (host state) veya üçüncü bir devletin tâbiiyetinde olan gerçek veya tüzel kişilerin, ev sahibi devletin uluslararası yatırım anlaşması imzaladığı bir devlette kurdukları şirketler yoluyla, yine ev sahibi devlete karşı başlattıkları tahkim davalarında gündeme gelmiştir. Bu bakımdan şirket tâbiiyetinin hakem kararlarında ele alınışı aşağıda tâbiiyet planlaması kavramı ekseninde ele alınacaktır.

\section{III.TÂBIIYYET PLANLAMASI VE YATIRIM TAHKİMI}

Uluslararası yatırım hukuku bakımından tâbiiyet planlaması şirketlerin

\footnotetext{
76 Agreement on Encouragement and Reciprocal Protection of Investments Between the Government of the People's Republic of China and the Government of the Kingdom of the Netherlands, <https://investmentpolicy.unctad.org/international-investment-agreements/ treaty-files/763/download > Erişim Tarihi 1 Haziran 2021.

77 RG: 29.06.2009 - 27270.

78 RG: 13.08 .1989 - 20251.

79 RG: 01.12.1997 - 23187.

80 Perkams, s. 14.
} 
yatırımın başlangıcı veya sonrasındaki bir dönemde kendisi için elverişli bir yatırım iklimi ve/veya hukuki alt yapı sunan bir devletin tâbiiyetini edinimidir. Örneğin Avrupa Birliği (AB) ülkeleri içerisinde bankacıllk yapmak isteyen Japon yatırımcı ilk aşamada kendisine uygun yatırım iklimi sunan Hollanda'da bir şirket kurup, diğer ülkelerdeki yatırımlarını Hollanda tâbiiyetinde bulunan bu şirket üzerinden gerçekleştirebilir. Keza ABD tâbiiyetinde olan bir şirket, kurmuş olduğu bir yavru şirket yoluyla Venezuela'da yatırım yaptıktan bir süre sonra, Venezuela ABD ilişkilerinin gerildiği bir dönemde şirket hisselerini Kanada'da kurulu olan veya bu amaçla kurmuş olduğu bir şirkete devredebilir ve bu yolla yatırımcının tâbiiyetini değiştirebilir.

Tâbiiyet planlamas1, uygun tâbiiyet (nationality of convenience) olarak da adlandırılmaktadır. Uygun tâbiiyet kavramı esas itibariyle deniz hukukunda geliştirilen elverişli bayrak (flag of convenience) kavramından türetilmiştir ${ }^{81}$. $\mathrm{Bu}$ kavram; geminin (ve mürettebatının) gerçek bağa sahip olmadığ elverişli bir devletin bayrağını çekme hakkına kavuşmasını tanımlamak için kullanılmaktadır ${ }^{82}$. Bayrak devletinin ise sicil kayıt parası gibi maddi birtakım menfaatler karşıllı̆ında gemi üzerindeki düzenleme ve denetim işlevini oldukça gevşek tuttuğu bilinmektedir ${ }^{83}$. Bu durum gemi sahipleri ve gemi işleticileri açısından düşük vergi, düşük tescil harcı gibi mali menfaatlerin yanı sıra denetime tabi olmayacak şekilde düşük ücretle işçi çalıştırma gibi birtakım kolaylıklar sağlamaktadır ${ }^{84}$.

Uygun bayrak uygulamasına benzer şekilde, şirketler tâbiiyet planlaması yoluyla daha az vergi verme, minimum sermaye şartını daha kolay bir şekilde yerine getirme veya ilgili devletin imzalamış olduğu ikili yatırım anlaşmaları ile sağlanan güvenceden yararlanma gibi kendisine uygun imkânlar sunan devletin tâbiiyetini edinebilir. Uluslararası yatırım hukuku bakımından diğer amaçlar da önemli olmakla birlikte tâbiiyet planlamasının asıl gayesinin bir yatırım anlaşmasının şemsiyesi altına girmek olduğu ifade edilebilir. Özellikle ikili yatırım anlaşmaları yoluyla uluslararası yatırım tahkimine başvurma imkânını elde etmek tâbiiyet planlamasının temel motivasyonunu

81 Casas, s. 65.

82 Sang Man Kim/ Jongho Kim, "Flags of Convenience in the Context of the OECD BEPS Package", 2018, 49(2),

Journal of Maritime Law \& Commerce, s. 221-222; Adam Boczek, Flags Of Convenience: An International Legal Study, Harward University Press, 1962, s. 2.

83 Boczek, s. 3; Kim/Kim; s. 222.

84 Boczek, s. 3-5; Aybay/Özbek/ Ersen Perçin, s. 301. 
oluşturmaktadır. Fiili olarak ise dünyanın farklı coğrafyalarında kurulmuş şirketlerin tâbiiyet planlaması yoluyla, yatırımların korunması konusunda yüksek standartlara sahip pek çok anlaşmaya taraf olan Hollanda gibi ülkelerin tâbiiyetine geçtikleri görülmektedir ${ }^{85}$.

Tâbiiyet planlaması ekseninde uygulamaya bakıldığında ise, hakemlerin çoğunlukla şekli tâbiiyet şartlarını yerine getiren yatırımcılar tarafından başlatılan uyuşmazlıklarda yarg1 yetkilerinin olduğuna karar verdikleri görülmektedir ${ }^{86}$. Diğer bir anlatımla yatırımcı şirketin ikili yatırım anlaşmasına taraf devlet kanunlarına uygun olarak kurulması yeterli sayılmakta, bunun ötesinde şirketin esaslı ekonomik faaliyetlerini o devlette yürütmesi, gerçek idare merkezinin o ülkede olması veya şirketin kurucuları olan gerçek kișilerinin vatandaşlığın kuruluş yeri devleti olması aranmamaktadır. Bu durum özellikle ikili yatırım anlaşmalarında kuruluş yeri esasının tek başına veya diğer esaslarla birlikte alternatif bir ölçüt olarak yer aldığ 1 anlaşmalar bakımından geçerlidir. Yatırım anlaşmalarının büyük bir kısmının kuruluş yeri esasına yer vermesi karşısında, hakem kararlarının bu yönde oluşmasını doğal karşılamak gerekir. Nitekim, ICSID altında yürütülen Champion Trading and Ameritrade v. Egypt davasında hakem heyeti Champion Trading ve Ameritrade şirketlerinin sermayesinin tamamının ABD ve Mısır çifte vatandaşlığına sahip Wahba ailesi bireylerine ait olmasına rağmen, şirketlerin ABD'de kurulmuş olmasını ve ABD ile Mısır ikili yatırım anlaşmasında başkaca bir kısıtlayıcı hüküm olmamasını gözeterek, yargılama yetkisini haiz olduğuna karar vermiştir ${ }^{87}$.

Yine ICSID kapsamında görülen Tokios Tokelés v. Ukraine davasında da hakem heyeti, yatırım tahkiminin dayanağını oluşturan Litvanya-Ukrayna ikili yatırım anlaşmasında, Litvanya açısından yatırımcının "Litvanya Cumhuriyeti kanunlarında uygun olarak kurulmuş herhangi bir kuruluş" şeklinde tanımlandığını, bunun ötesinde yatırımcı olarak kabul edilme açısından anlaşmada başkaca bir şartın bulunmadığını belirterek yargı yetkisini haiz olduğuna işaret etmiştir ${ }^{88}$. Davada Ukrayna tarafindan, davacı

\footnotetext{
85 Muthucumaraswamy Sornarajah, Good Faith, Corporate Nationality, and Denial of Benefits, in Andrew D Mitchell/ M Sornarajah/ Tania Voon (eds), Good Faith and International Economic Law, Oxford University Press, 2015, s. 121-122; Schreurer, s. 18.

86 Janig, s. 311.

87 Champion Trading Company and Ameritrade International, Inc. v. Arab Republic of Egypt (ICSID Case No. ARB/02/9), Decision on Jurisdiction, 21 October 2013, s. 18.

88 Tokios Tokelés v. Ukraine, para 28
} 
şirket Tokios Tokelés hisselerinin \% 99'unun Ukrayna vatandaşlarına ait olduğu, şirketin Litvanya' da esaslı bir ekonomik faaliyetinin bulunmadığı ve idare merkezinin (siège social) Ukrayna'da bulunduğu iddia edilmiş ve bu açıdan tüzel kişilik perdesinin kaldırılması talep edilmişse de; hakem heyeti ( $2 / 3$ çoğunluk kararıyla) anlaşmada tarafların açık iradeleri ile yer verdikleri kuruluş esası karşısında bu iddiaların geçerli kabul edilmeyeceğine karar vermiştir $^{89}$. Tokios Tokelés v. Ukraine davasından sonra da kuruluş yeri esasına yer veren yatırım anlaşmalarına dayanılarak ICSID kapsamında başlatılan yatırım tahkimi davalarında şirket tâbiiyeti konusunda istisnai bir karar ${ }^{90}$ dışında hakem heyetleri benzer şekilde hüküm kurmuşlardır ${ }^{91}$. Bu kapsamda KT Asia Investment Group B.V. v. Republic of Kazakhstan ${ }^{92}$, Gold Reserve v. Venezuela ${ }^{93}$, Burimi v. Albania ${ }^{94}$ davalarında hakemler şirket tâbiiyetlerine dayalı olarak yapılan yetki itirazlarını kuruluş yeri esasını uygulayarak reddetmişlerdir.

ICSID dışında yürütülen tahkim davalarında da yatırım tahkimine dayanak olan ikili yatırım anlaşmasında kuruluş yeri esasının benimsenmesi halinde, hakem heyetleri biçimsel incelemenin ötesine geçmemişlerdir. $\mathrm{Bu}$ kapsamda örneğin UNCITRAL tahkim kuralları altında cereyan eden Saluka Investments B.V. v. The Czech Republic davasinda hakem heyeti şirket tâbiiyetini, Hollanda ve Çek Cumhuriyeti arasındaki ikili yatırım anlaşmasında yer verilen "Hollanda kanunlarına uygun olarak kurulma" ifadesini temel alarak tespit etmiştir" ${ }^{95}$. Davaya konu olan olayda bankacılllik ve finansal hizmetler alanında pek çok ülkede kurmuş olduğu yavru şirketler (subsidiary) yoluyla faaliyet gösteren Japon Nomura Grubu, Birleşik Krallıkta Nomura

89 Tokios Tokelés v. Ukraine, para 28-71.

90 Venoklim Holding B.V. v. Bolivarian Republic of Venezuela, ICSID Case No. ARB/12/22, Award, 3 April 2015; Bahse konu davada hakem heyeti 2/3 çoğunlukla Hollanda kanunlarına göre kurulmuş olan Venoklim şirketinin Venezuela tâbiiyetinde olan şirketler tarafından kontrol edildiği gerekçesi ile Hollanda tâbiiyetinde sayılmayacağına karar vermiştir. Öte yandan bahse konu hakem kararı İspanyolca olup söz konusu kararı inceleyen yazarlardan davanın içeriği hakkına bilgi edinilmiştir. Kararın bu yönüyle tetik eden bir çalışma için bkz. Foote, s. 53-55.

91 McLachlan/ Shore/ Weiniger, s. 194-196.

92 KT Asia Investment Group BV v Kazakhstan, para 111-139.

93 Gold Reserve Inc. v. Bolivarian Republic of Venezuela, ICSID Case No. ARB(AF)/09/1, Award, 22 September 2014, para 248-255,

94 Burimi SRL v Albania, ICSID Case No ARB/11/18, IIC 593, Award, 29 May 2013, para 130.

95 Saluka Investments BV v. The Czech Republic, (UNCITRAL) PCA Case No. 2001-04, Partial Award, 17 March 2006, para 229. 
Europe isimli bir şirket kurmuştur. Nomura Europe Çek Cumhuriyeti'ndeki bankacılık özelleştirmesi sorasında IPB bankası hisselerini satın almıştır. Nomura Europe daha sonra satın almış olduğu bu hisseleri yine Nomura Grup tarafindan Hollanda'da kurulan Saluka şirketine devretmiştir. Çek Cumhuriyeti ile çıkan anlaşmazlık üzerine Saluka tarafindan başlatılan tahkim davasında, Çek Cumhuriyeti uyuşmazlığın gerçek tarafinın Nomura olduğunu öne sürerek yetki itirazında bulunmuştur ${ }^{96}$. Hakem heyeti ise yatırım anlaşmasında yer verilen kuruluş esasından ayrılmasının ancak anlaşmada aksi yönde bir hükmün varlığı halinde mümkün olacağını, böylesi bir hükmün yokluğunda ise gerçek bağ (genuie link) gibi anlaşmada yer almayan bir tanımı anlaşmaya dâhil etme konusunda yetkili olmadığını beyan ederek Saluka şirketi açısından yargı yetkisini haiz olduğuna karar vermiştir ${ }^{97}$. Aynı görüş Enerji Şartı Anlaşmasına dayalı olarak başlatılan Hutley Enterprises Ltd $v$ Russia davasında tekrar edilmiştir ${ }^{98}$.

Şirket tâbiiyeti konusunda merkez yeri esasına yer veren yatırım anlaşmalarına dayanan tahkim davalarında ise, hakem kararları merkez yeri kavramı olarak ana statüde gösterilen yerin (statutory seat) mi yoksa fiili/gerçek idare merkezinin (real seat, siege social reel) mi esas alınacağ 1 noktasında tutarlı değildir ${ }^{99}$. Kanaatimizce bu durum yatırım anlaşmalarında herhangi bir nitelemede bulunmadan merkez yeri (seat- Inglizce), (siege social- Fransizca), (Sitz- Almanca) ve (sede- Íspanyolca) ifadesinin kullanılmış olmasından kaynaklanmaktadır. Nitekim aşağıda daha detaylı olarak ele alınacağı üzere, kuruluş ve merkez yeri ifadelerine ilave olarak, şirketin gerçek ekonomik faaliyetlerinin kaynak ülkede yer almasını öngören anlaşmalar bakımından şirket tâbiiyetini belirleme konusunda hakem heyetleri bir sıkıntıyla karşılaşmamaktadır. Bu kapsamda örneğin, UNCITRAL tahkim kurallarına göre yürütülen Alps Finance and Trade $A G$ v. The Slovak Republic, davasında hakem heyeti; İsviçre ve Slovak Cumhuriyeti arasındaki iki taraflı yatırım anlaşmasında tüzel kişi yatırımeı tanımında geçen taraf ülke kanunlarına uygun olarak kurulma veya diğer şekilde teşekkül ettirilme (constituted or otherwise duly organized under the law of that Contracting

96 Saluka Investments BVv. The Czech Republic, para 199.

97 Saluka Investments BVv. The Czech Republic, para 227-229.

98 Hutley Enterprises Ltd $v$ Russia PCA Case No AA 226, IIC 415 UNCITRAL, Interim Award on Jurisdiction and Admissibility, 30 November 2009, para 411-417.

99 Yannick Radi, Rules and Practices of International Investment Law and Arbitration (Law in Context). Cambridge: Cambridge University Press, 2020, s. 413. 
party), merkez yerine sahip olma (have their seat) ve aynı taraf ülkede gerçek ekonomik faaliyetlere sahip olma (together with real economic activities, in the territory of that same Contracting Party) ifadelerinin tâbiiyetin tayini bakımından ayrı şartlar olduğunu tespit etmiş ve bir ülke kanunlarına uygun olarak kurulma ifadesinin aynı zamanda merkez yerine sahip olma anlamına gelmediğine karar vermiştir ${ }^{100}$. Hakem heyeti bu bağlamda bir şirketin merkezinden söz edebilmek için, ilgili ülkede yönetim kurulunun veya genel kurulun toplanması, belli sayıda çalışanın olması, telefon ve faks numaralarının bulunması veya üçüncü taraflarla sözleşmelerin burada yapılması gibi ilave birtakım öğelerin bulunması gerektiğine işaret etmiştir ${ }^{101}$. Hakem heyetinin merkez yerini, idare merkezi şekilde yorumlarken anlaşmada yer verilen "aynı taraf ülkede gerçek ekonomik faaliyetlere sahip olma" ifadesini dayanak olarak kabul ettiği konusunda şüphe yoktur.

Buna karş1lık böyle bir dayanaktan yoksun olarak yalnızca merkez yeri (seat, siege social, sede, sitz) kavramının kullanıldığı anlaşmalar bakımından hakem heyetleri farklı sonuçlara ulaşmışlardır. Nitekim ICSID kapsamında yürütülen Tenaris and Talta v. Venezuela davasında hakem heyeti Tenaris için Lüksemburg-Venezuela yatırım anlaşmasında geçen "siège social", Talta için ise Portekiz-Venezuela yatırım anlaşmasında yer verilen "sede" ifadesinin, "tescil yeri" veya "statüde gösterilen yer" ifadelerinin ötesinde bir anlamı içerdiği sonucuna ulaşmıştır ${ }^{102}$. Hakem heyeti bahse konu ifadelerin belli ölçüde şirket ile kurulduğu ülke arasında gerçek bağlantıyı gerektirdiği sonucuna ulaşmış ve bu ifadelerin davaya konu anlaşmalar temelinde gerçek ve efektif yönetim yeri (place of actual or effective management) anlamına geldiğini belirtmiştir ${ }^{103}$. Buna karşılık yine ICSID kapsamında yürütülen ve daha sonraki bir zamanda karara bağlanan Orascom TMT Investments S.à r.l. v. Algeria, davasında hakem heyeti tam tersi bir sonuca ulaşmıştır. Davaya konu olan olayda Cezayir, Orascom şirketi Lüksemburg'da tescil edilmiş olsa da yatırım ve günlük işlemler de dahil olmak üzere şirkete ilişkin kararların Kahire'den alındığını, bu anlamda idare edildiği yerin Kahire olduğunu

100 Alps Finance and Trade AG v. The Slovak Republic, UNCITRAL, Award, 5 March 2011, para 216.

101 Alps Finance and Trade AG v. The Slovak Republic, para, 217.

102 Tenaris S.A. and Talta - Trading e Marketing Sociedade Unipessoal Lda. v. Bolivarian Republic of Venezuela, ICSID Case No. ARB/11/26, Award, 29 January 2016, para 153.

103 Tenaris and Talta v. Venezuela, para 153-154. 
öne sürmüştür ${ }^{104}$. Hakem heyeti ise sözlük anlamından yola çıkarak "siège social" ifadesini statüde gösterilen yer (siège social statutaire) veya tescil yeri (registered office) şeklinde yorumlamıştır ${ }^{105}$. Hakem heyeti, ulaştığı bu sonuca dayanak olarak ikili yatırım anlaşması taraflarının kendi iç hukuklarına atıf yaparak "gerçek ekonomik faaliyet" veya "gerçek yönetim yeri" gibi bir durumu arzu etmiş olsalardı buna yönelik bir ifade kullanabileceklerini belirtmiştir ${ }^{106}$. Hakem heyeti ayrıca ulaştığı bu sonuca dayanak olarak UAD'ın Barcelona Traction davasında yer verdiği ve UHK'nın Diplomatik Korumaya İlişkin Taslak Maddelerinde ifadesini bulan teamül hukukunu da gerekçe göstermiştir ${ }^{107}$. Bu bağlamda, hakem heyeti "merkez yeri" kavramını "ana statüde gösterilen yer" veya "tescil yeri" şeklinde ele alarak şirketlerin tâbiiyetinin tayini meselesi konusunda kuruluş yeri esasına yaklaşmıştır.

Kanaatimizce yatırım tahkimi davalarında şirket tâbiiyetinin şekli olarak ele alınmasının iki önemli sebebi bulunmaktadır. İlk olarak, başta gelişme yolundaki ülkeler olmak üzere, devletler 1995 yılına kadar yaptıkları yatırım anlaşmalarında yatırımcı tanımına çok fazla önem atfetmemişlerdir ${ }^{108}$. Bu dönem içerisinde uluslararası yatırım çekmek isteyen gelişme yolundaki devletler, gelişmiş ülkeler tarafından önlerine getirilen anlaşmaları içeriğine çok fazla vâkıf olmadan imzalamışlardır. Hatta yatırım anlaşmaları devlet başkanları veya yatırımlardan sorumlu bakanların üst düzey ziyaretleri sırasında imzalanan rutin anlaşmalar olmuştur. Yatırım anlaşmalarının ekseriyetinde ise yalnızca kuruluş esasının veya diğer esaslarla birlikte kuruluş esasına yer verilmesi tâbiiyet planlamasını kolaylaştırmıştır. Merkez yeri esasının yer verildiği anlaşmalar bakımından ise bu kavramdan ne anlaşılması gerektiğinin anlaşma içerisinde yer verilmemesi merkez yeri kavramının hakemler tarafından statüde gösterilen yer şeklinde ele alınmasına neden olmuştur. Şirket tâbiiyetinin şekli olarak ele alınmasının diğer nedeninin ise hakemlerin yarg1 yetkisini belirleme konusundaki tutumlarından kaynaklandığ1 değerlendirilmektedir. Bu bağlamda hakemlerin yargı yetkilerini tespit ederken yatırımcı tanımını genişletici bir şekilde yorumlamaları tâbiiyet planlamasını kolaylaştırmıştır.

\footnotetext{
104 Orascom TMT Investments S.à r.l. v. People’s Democratic Republic of Algeria, para. 194208

105 Orascom TMT Investments S.à r.l. v. Algeria, para. 282-298.

106 Orascom TMT Investments S.à r.l. v. Algeria, para. 279.

107 Orascom TMT Investments S.à r.l. v. Algeria, para. 290-296

108 Foote, s. 24.
} 
Öte yandan, hakem heyetlerinin kuruluş yeri esasının benimsendiği anlaşmalara dayalı olarak başlatılan uyuşmazlıklarda şirket tâbiiyetini biçimsel olarak ele alması, merkez yeri esasına yer veren anlaşmalarda ise bu esası tescil yeri veya statüde gösterilen yer şeklinde yorumlaması kabuk veya paravan şirketlerin (shell company) yatırım anlaşmaları ile getirilen korumadan yararlanmalarının önünü açmıştır. Bu duruma tepki olarak bazı hakem kararları kabuk veya paravan şirketler tarafından başlatılan tahkim süreçlerini hakkın kötüye kullanılması (abuse of rights) veya sürecin kötüye kullanılması (abuse of process) olarak değerlendirmiştir ${ }^{109}$. Ayrıca devletler de son dönemde imzaladıkları bazı yatırım anlaşmalarında "kuruluş yeri” ve "merkez yeri" esaslarına ilave olarak, yatırımcının, tâbiiyetinde bulunduğu ülkede esaslı (substantial) veya gerçek (real) ekonomik faaliyetinin bulunması koşuluna yer vermektedir. Diğer bazı anlaşmalarda ise, tâbiiyetinde olduğu ülkede gerçek ekonomik faaliyeti bulunmayan tüzel kişilerin anlaşma ile sağlanan faydalardan yararlandırılmayacağına (denial of benefits) yönelik hükümler konulmaktadır. Aşağıda bu konular üzerinde durulacaktır.

\section{IV.TÂBIIIYET PLANLAMASINA KARŞI GELIŞTIRILIEN TEPKILER}

\section{A. HAKKIN KÖTÜYE KULLANILMASI YASAĞI}

Normal olarak yatırım tahkimine başvurma imkânı olmayan gerçek veya tüzel kişilerin, ev sahibi devlet ile yatırım anlaşması bulunan bir ülkede kabuk veya tabela şirketler kurup, bu şirketler yoluyla yatırım tahkimine başvurmaları bazı hakemlerin itirazı ile karşılaşmıştır. Bunun en önemli örneği yukarıda içeriği açıklanan Tokios Tokelés v. Ukraine davasında yaşanmıştır. Anılan davada Ukrayna vatandaşları tarafindan Litvanya'da kurulan ancak

109 Hakkın kötüye kullanılması (abuse of rights) yasağı, bir kişinin bir hakkı, diğer kişilerin kendi haklarından yararlanmasını engelleyecek şekilde veya hakkın yaratıldığ 1 amaçtan farklı bir amaçla diğer kişilerin zararına olarak kullanmasını ifade eder. Sürecin veya usulün kötüye kullanılması (abuse of process) ise usule ilişkin bir hakkın amacının ötesinde diğer tarafi zarara uğratmak amacıyla kullanılmasını ifade eder. $\mathrm{Bu}$ anlamda sürecin kötüye kullanılmasının hakkın kötüye kullanılmasının özel bir hali olduğu söylenebilir. Uluslararası yatırım hukuku bakımından bazı yazarlarca bu iki kavram birbiri yerine kullanılmakta olup, genellikle yatırımcının yatırım tahkimi sürecine amacının ötesinde başvurmasını belirtmek bakımından kullanılmaktadır. Bu çalışmada daha genel bir kavram hakkın kötüye kullanılması kavramı tercih edilecektir. Uluslararası yatırım hukuku bakımından bu kavramların kullanılışı ve birbirleri arasındaki farkları açıklayan bir çalışma için bkz. Tania Voon/ Andrew Mitchell/ James Munro, "Legal Responses to Corporate Manoeuvring in International Investment Arbitration", 2014, 5(1), Journal of International Dispute Settlement, s. 60-61. 
gerçek faaliyetlerini Ukrayna'da yürüten Tokios Tokelés şirketinin Ukrayna aleyhine açtığı tahkim davasında, hakem heyeti çoğunluk kararı ile yargı yetkisini haiz olduğuna karar vermişse de; bu karara aynı zamanda hakem heyetinin başkanlığını yapan Prosper Weil tarafından güçlü bir muhalefet şerhi düşülmüştür. Weil'e göre "ICSID mekanizması ev sahibi devletin tâbiiyetinde bulunan kişilerin, yabancı bir ülkede daha önceden veya sirf bu amaç için kurulmuş bir şirket üzerinden, yerel mahkemeler ve yerel hukuku atlayarak uyuşmazlığı uluslararası tahkime taşımalarına izin veren, hatta bunu teşvik eden bir mekanizma değildir. ICSID mekanizmasının yegâne amacı uluslararası yatırımları teşvik etmektir ${ }^{110}$." Weil uluslararası yatırımc1 şirketten bahsedebilmek için şirketin kaynak ülke kanunlarına uygun olarak kurulması yanında bu şirkete ait yatırımın gerçek bir uluslararası yatırım olup olmadığının araştırılması gerektiğini öne sürmüştür ${ }^{111}$. Diğer bir anlatımla Weil'e göre şirket kaynak devlette kurulmakla birlikte, şirketin dolayısıyla yatırımın gerçek anlamda başka bir devlet tâbiiyetinde bulunan kişiler tarafindan kontrol edilmesi durumda ICSID kapsamında yatırım tahkimine başvurma hakkı bulunan bir yatırımcıdan söz edilemeyecektir.

Bununla birlikte yukarıda ifade edildiği üzere yatırım anlaşmasında "gerçek ekonomik faaliyet" veya "gerçek yönetim yeri" gibi yatırımcı ile kaynak ülke arasında gerçek bağı arayan bir tanımlama yapılmadığı müddetçe Weil tarafindan öne sürülen bu görüş uygulamada kabul görmemiştir ${ }^{12}$. Bununla birlikte Weil'in görüşü içerisinde dile getirilen endişenin haklı bir gerçeklik payı içerdiği de kuşkusuzdur. Zira bu görüşün tümüyle reddedilmesi, ev sahibi devlette yatırımı bulunan ancak uluslararası yatırım tahkimine gitme hakkı bulunmayan şirketlerin, uyuşmazlığın çıkacağını hissettiklerinde veya uyuşmazlık çıktıktan sonra; yatırımlarını ev sahibi devletle yatırım anlaşması bulunan bir devlette halihazırda kurulu olan veya bu amaçla kurulacak bir şirket altında yapılandırarak, yatırım tahkimine başvurmalarının önünü açmaktadır. Teorik olarak bu durum yatırım uyuşmazlıkları bakımından ev sahibi devletin mahkemeleri ve hukukunun tümüyle atlanması (bypass) sonucunu doğurabilecektir ${ }^{113}$.

110 Tokios Tokelés v. Ukraine, ICSID Case No. ARB/02/18, Dissenting Opinion (Chairman Prosper Weil), 29 April 2014, para 30; Çeviri yazar tarafından yapılmıştır.

111 Tokios Tokelés v. Ukraine, Dissenting Opinion (Chairman Prosper Weil), para 20.

112 McLachlan/ Shore/ Weiniger, s. 194-196; Schreuer/ Malintoppi/ August Reinisch/ Anthony Sinclair Schreuer, Commentary, s. 290.

113 Tokios Tokelés v. Ukraine, Dissenting Opinion (Chairman Prosper Weil), para 23. 
Son dönemde uygulamaya da yansiyan bu durum bazı hakem heyetlerince hakkın kötüye kullanılması yasağı kapsamında ele alınmıştır ${ }^{114}$. Bazı hakem heyetleri tâbiiyet planlamasının amacını diğer bazıları ise tâbiiyet planlamasının amacı yanında zamanını dikkate alarak, tâbiiyet ediniminin hakkın kötüye kullanılması teşkil edip etmediğini değerlendirmiştir ${ }^{115}$. Tâbiiyet ediniminin amacı yönünden hakkın kötüye kullanılması olarak değerlendirildiği bir durum Phoenix Action Ltd. v. Czech Republic davasında yaşanmıştır ${ }^{116}$. Davaya konu olan olayda Çek Cumhuriyeti vatandaşı olan Vladimir Beno Çek Cumhuriyeti'nde kendisine karşı yürütülen soruşturmalar neticesinde İsrail'e yerleşmiş ve 2001 yılı Kasım ayında Phoenix şirketini kurmuştur. 2002 yılı Aralık ayında ise Phoenix, Beno ailesine ait olan ve Çek Cumhuriyeti'nde özel kişiler ve devletle davaları süren Benet Praha ve Benet Group şirketlerinin hisselerini nominal değer üzerinden satın almıştır. Phoenix Şubat 2004'te ise Çek Cumhuriyeti'ne karşı İsrail-Çek Cumhuriyeti yatırım anlaşmasına dayanarak ICSID tahkimini başlatmıştır. Çek Cumhuriyeti söz konusu davada yeki itirazında bulunarak Phoenix'in yatırım tahkimine başvurmak için kurulmuş sahte (sham) bir şirketten başka bir şey olmadığııı iddia etmiştir ${ }^{117}$. Söz konusu davada hakem heyeti, İsrail kanunlarına uygun olarak kurulmuş olan Phoenix' in anlaşma kapsamında yatırımcı olduğunu belirlemiş, ancak somut vakıalar temelinde şirketin ekonomik faaliyette bulunmak amacıyla değil, yalnızca Çek Cumhuriyeti'ne karşı uluslararası dava açmak amacıyla bir "yatırım" yaptığını tespit etmiştir ${ }^{118}$. Hakem heyetine göre bu tür bir işlem, ICSID Konvansiyonu ile koruma altına alınan bir yatırım olmayıp, işlemin tek amacı önceden var olan bir iç anlaşmazlığı, ikili yatırım anlaşması kapsamında ICSID tahkimine tabi uluslararası bir anlaşmazlığa dönüştürmektir ${ }^{119}$. Hakem heyeti netice olarak bu işlemi, iyi niyetli saymayarak hakkın kötüye kullanılması yasağ kapsamında değerlendirmiştir ${ }^{120}$.

Tâbiiyet planlamasının amacı yanında zamanını dikkate alan

\footnotetext{
114 Mark Feldman, "Setting Limits on Corporate Nationality Planning in Investment Treaty Arbitration”, 2012, 27(2) ICSID Review, s. 282.

115 Feldman, s. 282.

116 Phoenix Action, Ltd. v. The Czech Republic, ICSID Case No. ARB/06/5, Award, 15 April 2009.

117 Phoenix Action, Ltd. v. The Czech Republic, para, 34.

118 Phoenix Action, Ltd. v. The Czech Republic, para, 142.

119 Phoenix Action, Ltd. v. The Czech Republic, para, 142.

120 Phoenix Action, Ltd. v. The Czech Republic, para, 143-144.
} 
hakem kararları ise yatırım tahkimine erişim hakkına kavuşma amacıyla gerçekleştirilenler de dahil olmak üzere tâbiiyet edinimini kural olarak meşru kabul etmektedir ${ }^{121}$. Buna mukabil tâbiiyet ediniminin, yatırımcı ile ev sahibi devlet arasındaki problemin uyuşmazlığa dönüşmesinin yüksek bir ihtimal olarak değerlendirildiği bir zamanda gerçekleştirilmesi halinde, tâbiiyet planlaması hakkın kötüye kullanılması olarak değerlendirilmektedir ${ }^{122}$. $\mathrm{Bu}$ bağlamda hakemlerce yatırımcı ile ev sahibi devlet arasında henüz bir uyuşmazlık ihtimalinin olmadığı bir dönemde, yatırımcının kendisini gelecekte ortaya çıkması muhtemel genel risklere karşı güvence altına almak için yapmış olduğu tâbiiyet edinimi kendiliğinden (per se) gayrimeşru kabul edilmemiştir $^{123}$. Bu husus Tidewater v. Venezuela davasında hakem heyetince şu şekilde açıklanmıştır: "Bir yatırımcının, ev sahibi ülke ile gelecekteki anlaşmazlıkların genel riskinden bu şekilde [tâbiiyet planlamast yoluyla] ${ }^{124}$ kendisini korumaya çalışması, tamamen meşru bir hedeftir ve bir yatırım koruma anlaşması rejiminin kötüye kullanılması değildir. ${ }^{125 " ~ B u n u n l a ~}$ birlikte hakkın kötüye kullanılması sayılan tâbiiyet planlaması uyuşmazlık çıktıktan veya spesifik uyuşmazlığın sadece bir ihtimal değil, çok yüksek bir olasılık olduğu zamanda gerçekleştirilen tâbiiyet edinimidir. Bu halde tâbiiyet ediniminin zamanlaması kritik önemi haizdir ${ }^{126}$. Tâbiiyet edinimi veya tâbiiyet değişikliği uyuşmazlık çıkmazdan evvel yeterli bir öngörüyle gerçekleştirildiğinde meşru kabul edilecek, tersi durumda yani ev sahibi devlet ile yatırımcı arasında yaşanan problemin uyuşmazlığa dönüşme ihtimalinin yüksek olduğu bir dönemde gerçekleştirildiğinde hakkın kötüye kullanılması olarak değerlendirilecektir ${ }^{127}$.

Uyuşmazlık çıktıktan sonra yatırım tahkimine gitme amacıyla yapılan

121 Demirkol, s. 324.

${ }^{122}$ Casas, s. 116.

123 Mobil Cerro Negro Holding, Ltd. v. Venezuela, ICSID Case No. ARB/07/27, Decision on Jurisdiction, 10 June 2010, para 204; Philip Morris Asia Limited v. The Commonwealth of Australia, UNCITRAL, PCA Case No. 2012-12, Award on Jurisdiction and Admissibility, 17 December 2015; para 540; Tidewater v. Venezuela, ICSID Case No. ARB/10/5, Decision on Jurisdiction, 8 February 2013, para 184.

124 Konunun anlaşılması açısından "bu şekilde" ifadesinin anlamını açıklamak bakımından yazar tarafindan eklenmiştir.

125 Tidewater v. Venezuela, para 184.

126 Voon/ Mitchell/ Munro, s. 46-47.

127 Casas, s. 116; Pac Rim Cayman LLC v. Republic of El Salvador, ICSID Case No. ARB/09/12, Decision on the Respondent's Jurisdictional Objections, 1 June 2012, para 2.99. 
tâbiiyet değişikliğinin hakemler tarafından tespiti nispeten kolaydır. Buna mukabil uyuşmazlık çıkmadan önce gerçekleştirilen tâbiiyet değişikliğinin yatırım tahkimine gitme amacıyla mı yoksa vergi kolaylıkları veya yatırım anlaşmasının koruması altına girme konusundaki genel bir öngörü mü olduğunun tespiti kolay olmayacaktır. Hiç şüphesiz böylesi bir tespit vakıalara dayanmak durumundadır. Philip Morris Asia Limited v. The Commonwealth of Australia davasında hakem heyeti davacı yatırım şirketi ile ev sahibi devlet arasında uyuşmazlık çıkmadan önceki iki yılda yapılan yazışmalar yanında yine davacının sahip olduğu şirketler grubu ile hukuk danışmanları arasındaki yazışmalara bakarak tâbiiyet değişikliğinin amacının yatırım tahkimine gitmek olduğunu belirlemiş ve bu durumu hakkın kötüye kullanılması yasağ içerisinde değerlendirmiştir ${ }^{128}$. Söz konusu davaya konu olan olayda Avusturalya'nın tütün ürünlerinin düz paketlenmesine ${ }^{129}$ yönelik yasa hazırlıklarının devam ettiği süreçte, çok uluslu bir şirket olan Philip Morris bu konuda düzenleme yapılmasına şiddetli bir şekilde karşı çıkmış, uygulamanın yasalaşması halinde yatırım tahkimi dahil ulusal ve uluslararası tüm yarg1 süreçlerine başvuracağını Avusturalya'ya bildirmiştir ${ }^{130}$. Düz paketleme düzenlemesinin yasalaşacağının anlaşıldığ Philip Morris Avustralya tâbiiyetinde bulunan Philip Morris Australia'a ait varlıkları yeniden yapılandırılarak Hong Kong tâbiiyetinde bulunan Philip Morris Asia'nın altına almıştır. Yeniden yapılandırma düz paketleme yasasının yürürlüğe girmesi öncesinde tamamlanmış ve düzenlemenin yürürlüğe girdiği günün ertesinde Philip Morris Asia Avusturalya'ya karşı yatırım tahkimi davası açmıştır. Hakem heyeti bu davada kişi bakımından yargı yetkisini haiz olduğunu belirlemiş, ancak tâbiiyet planlamasının uyuşmazlığın çıkmasının yüksek bir şekilde beklendiği dönemde gerçekleştirildiğini belirterek, Philip Morris Asia tarafından yapılan başvuruyu hakkın kötüye kullanılması olarak değerlendirmiştir ${ }^{131}$.

128 Philip Morris Asia Limited v. The Commonwealth of Australia, para 555-569.

129 Düz paketleme ifadesi tütün mamullerinin standart bir renkte (genellikle koyu kahverengi) paketlenmesini ve paket üzerinde marka ve ürün adının belli bir yazı tipi stili ve boyutunda yer alması dışında logo ve marka tasvirine yönelik işaretlerin konulmasını yasaklayan düzenlemeleri tanımlamak için kullanılmaktadır.

130 Tütün ürünlerinin düz paketlenmesinin uluslararası ticaret ve yatırım hukuku bakımından doğurduğu sonuçları inceleyen bir çalışma için bkz. Talat Kaya, "Uluslararası Ticaret ve Yatırım Hukuku Bakımından Tütün Ürünlerinin Düz Paketlenmesi Meselesi”, 2018, 24(2), Marmara Üniversitesi Hukuk Fakültesi Hukuk Araştırmaları Dergisi, s. 1045-1085.

131 Philip Morris Asia Limited v. The Commonwealth of Australia, para 585-588. 
Kanaatimizce hakem heyetlerinin yalnızca amacına bakarak tâbiiyet planlamasını hakkın kötüye kullanılması yasağı içerisinde değerlendirmeleri hatalı olacaktır. Zira uluslararası yatırım yapan şirketler açısından başka bir ülkede yatırım yapmak her zaman riskli bir durumdur. Uyuşmazlık çıkması halinde ise özellikle hukuki gelişmişlik açısından daha geride olan ülkelerde iç hukuk yollarına başvurularak adil bir karar almak güç olabilmektedir. $\mathrm{Bu}$ anlamda yatırımın genel anlamda doğurduğu riskten kaçınmak amacıyla uluslararası yatırımcıların, ev sahibi devletin yatırım anlaşması bulanan bir ülkede kurulacak şirket yoluyla yatırımını gerçekleştirmesi meşru kabul edilmelidir. Buna mukabil başlangıçta böyle bir öngörü ile hareket etmeyen ancak uyuşmazlık çıktıktan sonra sırf uyuşmazlığın görüleceği yerin değiştirilmesi amacıyla, tâbiiyet planlaması yoluyla yapılan hukuki manipülasyonların ise hakkın kötüye kullanılması yasağı kapsamında değerlendirilmesini doğru bulduğumuzu vurgulamak isteriz. Hülasa kanaatimizce tâbiiyet planlaması kendiliğinden (per se) hakkın kötüye kullanılması yasağı içerisinde değerlendirilmemeli buna mukabil, ev sahibi devlet ile uyuşmazlığın çıktığı veya çıkmasının çok yüksek bir ihtimal olduğu dönemde sırf yatırım tahkimine gitmek için gerçekleştirilen tâbiiyet edinimleri bu yasak kapsamında ele alınmalıdır.

\section{B. YATIRIM ANLAŞMALARINDA YATIRIMCI TANIMININ DARALTILMASI ve FAYDALARIN REDDİ (DENIAL OF BENEFITS) HÜKÜMLERINE YER VERÍLMESİ}

Kabuk veya tabela şirketlerin yatırım tahkimine sıkça başvurmaları karşısında devletler son dönemde imzaladıkları yatırım anlaşmalarında "kuruluş yeri" ve "merkez yeri" esaslarına ilave olarak, yatırımcının, tâbiiyetinde bulunduğu ülkede esaslı (substantial) veya gerçek (real) ekonomik faaliyetinin bulunması koşuluna yer vermektedir. Bu kapsamda örneğin yakın dönemde Türkiye ile Bangladeş arasında imzalanan YKTK Anlaşmasında ${ }^{132}$ tüzel kişiler bakımından yatırımc1 “...faaliyetlerinin önemli bir bölümü bir Akit Taraf ülkesinde bulunan ve o Akit Tarafin yürürlükteki mevzuatı çerçevesinde kurulmuş veya teşekkül etmişşirketleri, firmaları veya iş ortaklıklarını ifade eder" şeklinde tanımlanarak, anlaşma ile sağlanan haklardan yararlanmak için kuruluş yeri esasına ilave olarak şirket faaliyetlerinin önemli bir bölümünün şirketin kurulduğu ülkede bulunması aranmıştır. Keza Türkiye ile

132 RG: 10.05 .2019 - 30770. 
ÇHC arasında imzalanan YKTK Anlaşmasında ${ }^{133}$ ise tüzel kişiler açısından yatırımc1 "Akit Taraflardan birinin hukuku çerçevesinde kurulmuş veya teşekkül etmiş ve kayttl yönetim merkezleri ile birlikte yeterli seviyedeki iş faaliyetleri söz konusu Akit Taraf ülkesinde bulunan şirketleri, firmalart veya iş ortaklıklarını ifade eder" şeklinde tanımlanarak idare merkezi esasına ilave olarak, şirketin kurulduğu âkit tarafta yeterli seviyede iş faaliyetinin bulunması şart koşulmuştur.

Önemli veya yeterli ekonomik faaliyette bulunma şartı, yatırım anlaşması ile tanınan haklardan yalnızca diğer taraf yatırımcılarının yararlanmasını amaçlamaktadır. Diğer bir anlatımla, yatırımcı tanımının bu şekilde daraltılması genel olarak ev sahibi devlet veya üçüncü bir devlet yatırımcılarına ait tabela şirketlerini yatırım anlaşması koruması dişında bırakmayı hedefler. Daraltıcı tanımlama özel olarak ise tabela şirketlerinin âkit taraflara karşı yatırım tahkimi davası açmalarını önleme amacını taşır. Esasen daraltıcı bu tanımlama yatırımcı tanımını geniş bir şekilde yorumlayan hakem kararlarına devletler tarafından verilen bir cevap niteliği de taşır. Zira yukarıda ifade edildiği üzere pek çok hakem heyeti, yatırım tahkimine dayanak olan ikili yatırım anlaşmalarında yatırımcı için "gerçek ekonomik faaliyet" veya "gerçek yönetim yeri" kriterlerin olmadığından bahisle; kişi bakımından yetkisini tayin ederken biçimsel incelemenin ötesine geçmemiştir. Diğer bir anlatımla hakem heyetleri, yatırım anlaşmasına taraf olan devletlerin iradeleri hilafına yatırım anlaşmasında olmayan bir kriteri kendileri ekleyerek yatırımcı tanımını daraltmayı uygun görmemişlerdir ${ }^{134}$. İşte bu noktada devletlerin yatırım anlaşması ile yatırımcı tanımını sınırlandırmaları hakemlerin bu sınırlamayı göz önüne almalarını sağlayan bir mekanizma olmuştur. Nitekim, yukarıda ele alındığı üzere Alps Finance and Trade AGv. The Slovak Republic, davasında hakem heyeti; İsviçre ve Slovak Cumhuriyeti arasındaki iki taraflı yatırım anlaşmasında yatırımcı tanımı içerisinde geçen "aynı taraf ülke de gerçek ekonomik faaliyetlere sahip olma" ifadesini dikkate alarak, kavramı dar yorumlamış ve yargı yetkisini haiz olmadığına karar vermiştir ${ }^{135}$.

Tabela şirketlerinin yatırım tahkimine başvurmalarının önlenmesi bakımından devletlerin kullandıkları diğer bir yöntem yatırım anlaşmalarına

\footnotetext{
133 RG: 01/10/2020 - 31261 (Mükerrer)

134 Sornarajah, s. 118.

135 Alps Finance and Trade AG v. The Slovak Republic, para. 219-227.
} 
faydaların veya menfaatlerin reddi (denial of benefits) hükmü koymaktır ${ }^{136}$. Faydaların reddi hükmü yatırım anlaşmalarına görece yeni girmiş olmakla birlikte, bu hükümlerin uluslararası anlaşmalarda kullanılması yeni değildir. Faydaların reddi hükümlerinin kaynağı II. Dünya Savaşı sonrasında ABD ile Japonya arasında imzalanan Dostluk Ticaret Seyrüsefer Anlaşması'na dayanır ${ }^{137}$. Söz konusu hüküm üçüncü devletlerin anlaşma ile sağlanan faydalardan yararlanmasını engellemek amacıyla anlaşmaya derç edilmiştir ${ }^{138}$. Faydaların reddi hükmü sonraki zaman dilimi içerisinde çeşitli anlaşmalarda kullanılmış, 1990'lı yılların ortalarında ise ABD, Kanada, Meksika, Japonya, Kore, ÇHC, Avusturalya, Yeni Zelanda ve Peru gibi pek çok ülke tarafından imzalanan yatırım anlaşmaları içerisinde yerini almıştır ${ }^{139}$. Yine USMCA ${ }^{140}$ ve Enerji Şartı Anlaşmas ${ }^{141}$ faydaların reddi hükümlerine yer veren önemli anlaşmalar arasında sayılabilir. Türkiye de yakın dönemde imzaladığı bazı yatırım anlaşmalarına faydaların reddi hükmünü koymuştur. Bu kapsamda örneğin Türkiye ile Güney Kore arasında imzalanan yatırım anlaşması m.1.15 hükmü şu şekildedir: “ 1. Bir Akit Taraf, işbu Anlaşma'dan kaynaklanan faydaların, diğer Akit Taraf'ın bir işletmesi olan bu Akit Taraf'ın bir yatırımcisina ve bu gibi bir yatırımcinın yatırımlarına uygulanmasını, söz konusu şirketin kanunları çerçevesinde teşekkül etmişs olduğu Akit Taraf'in ülkesinde önemli faaliyetlerinin olmaması veya Anlaşma'ya taraf olmayan bir ülkenin yatırımcısının veya Anlaşma'nın faydalarının uygulanmasııı reddeden Akit Taraf'ın yatırımcılarının bu işletmeye sahip olması veya idare etmesi halinde reddedebilir.

2. Reddeden Akit Taraf, menfaatleri reddetmeden önce, mümkün olduğu ölçüde, diğer Akit Taraf'a bildirimde bulunacaktır. Reddeden Akit Taraf'ın böyle bir bildirimde bulunması halinde, diğer Akit Taraf'ın talebi üzerine o

\footnotetext{
136 Sornarajah, s. 120.

137 Richard Happ, "Denial of Benefits Clauses and any other Mechanisms that Limit the Scope of BITs for Investors" in The Determination of the Nationality of Investors under Investment Protection Treaties, Institute of Economic Law (Transnational Economic Law Research Center), 2011, s. 61; Xiao-Jing Zhang, "Proper Interpretation of Corporate Nationality under International Investment Law to Prevent Treaty Shopping" 2013, 6(1), Contemporary Asia Arbitration Journal, s. 57.

138 Happ, s. 61-62.

139 Casas, s. 88.

140 USMCA, Madde 14.14;

141 Enerji Şartı Anlaşması, Madde 17.
} 
Akit Taraf'la istişarede bulunacaktır.142,"

Yukarıda yer verilen örnek ifadeden hareketle faydaların reddi hükmünün uygulanması için üç unsurun tespiti gereklidir. İlk olarak şirketin diğer kaynak ülke tâbiiyetinde olmakla birlikte, gerçekte üçüncü bir ülkenin veya ev sahibi devletin yatırımcılarına ait olduğu tespit edilmelidir ${ }^{143}$. Şirketin sahibinin kim olduğu veya kimin tarafından idare edildiği tescil yeri ülkesindeki kayıtlara, şirketin gerçekleştirdiği işlemler ile somut olayın şartlarına bakılarak tespit edilecek hususlardır. Faydaların reddi hükmü kapsamında ikinci olarak şirketin kurulduğu (teşekkül ettirildiği) ülkedeönemli faaliyetinin olmaması icap eder ${ }^{144}$. Önemli ticari faaliyet kriteri konusunda genel olarak yatırım anlaşmalarında açıklık bulunmamaktadır ${ }^{145}$. Bu kriterin karşılanıp karşılanmadığı hakem heyetlerince olay bazında değerlendirilmektedir ${ }^{146}$. Ancak hakem kararlarında "önemli faaliyet” eşiğinin yüksek tutulmadığı, kaynak ülkedeki faaliyetlerin büyük ölçekli veya kapsamlı olmasının aranmadığı görülmektedir ${ }^{147}$. Örneğin Enerji Şartı Anlaşması'na dayanılarak başlatılan ve Stockholm Ticaret Odası tahkim kurallarına göre yürütülen Limited Liability Company Amto v. Ukraine davasında hakem heyeti şirketin kaynak ülkede ofisinin olması, bu ülkede vergi vermesi ve yerel istihdam oluşturmasını önemli faaliyet olarak yeterli saymıştır ${ }^{148}$.

Faydaların reddi hükmünün uygulanması için son şart olarak, ev sahibi devletin bunu yatırımciya bildirmesi zarureti bulunmaktadır ${ }^{149} . \mathrm{Bu}$ noktada bildirimin yapılma zamanı faydaların reddi hükmünün spesifik olay bakımından uygulanması açısından hayati önemi haizdir. Bildirimin zamanı konusunda ise farklı görüşler ortaya atılmıştır. İlk görüş ev sahibi devlet tarafından faydaların reddi hükmünün uygulanmasının bildirimi konusunda herhangi bir zaman kısıtlamasının olmaması gerektiğini öne sürmektedir. Bu bağlamda ev sahibi devlet uyuşmazlık çıktıktan, hatta tahkim süreci başladıktan

\footnotetext{
142 RG: 05.06.2018 - 30422 (Mük.)

143 Voon/ Mitchell/ Munro, s. 54.

144 Voon/ Mitchell/ Munro, s. 54.

145 Happ, s. 64; Zhang, s. 58.

146 Happ, s. 64-65.

147 Zhang, s. 58.

148 Limited Liability Company Amto v. Ukraine, SCC Case No. 080/2005, Final Award, 26 March 2008, para 68.

149 Sornarajah, s. 137.
} 
sonra dahi bu hükme dayanarak yargı yetkisi itirazında bulunabilecektir ${ }^{150}$. Buna mukabil hakem heyetlerinin ekseriyeti tarafindan benimsenen ikinci görüş ise, faydaların reddi hükmüne dayalı olarak yargı yetkisi itirazının kabul edilmesi için; ev sahibi devletin bildirimini spesifik uyuşmazlıkla ilgili tahkim süreci başlamadan hatta yatırımcı ile ev sahibi devlet arasında problem ortaya çıkmazdan önce yapması gerektiğini savunmaktadır ${ }^{151}$. Diğer bir anlatımla faydaların reddi hükmü ancak bildirimin yapılmasından sonraki zaman dilimi için ileriye dönük olarak uygulama alanı bulacaktır. Ev sahibi devletin her bir yatırımcının kimliğine bakarak faydaların reddi hükmünün kime karşı uygulanacağını tespitinin zorluğu bir yana yatırım sahipliğin yatırım yapılmasından sonraki zamanda değişebilmesi, hükmün ev sahibi devlet açısından kullanımını hayli zorlaştırmaktadır ${ }^{152}$. Ev sahibi devlet açısından ortaya çıkardığı tüm zorluğa rağmen kanaatimizce de faydaların reddi hükmünün uygulanması bakımından ev sahibi devlet tarafından yapılacak bildirim uyuşmazlık öncesinde yapılmalıdır. Aksine bir durum yatırım yapıldığı anda uluslararası yatırım tahkimi başvuru imkânının olduğunu düşünen yatırımcıları güçlü taraf olan devlet karşısında korumasız birakacaktır.

$\mathrm{Bu}$ bağlamda uygulamada da faydaların reddi hükmünün hakem heyetlerince kısıtlayıcı şekilde yorumlanması, tâbiiyet planlamasına karşı bu hükmün kullanılmasını sınırlandırmaktadır. Bu durum biryönüyle başa dönmek ve yatırımcı tâbiiyeti konusunda anlaşmada yer verilen tanımın ön plana çıkması anlamına gelmektedir. Diğer bir anlatımla ikili yatırım anlaşmasında yatırımcının yalnızca kuruluş yeri veya herhangi bir niteleme veya bağlamdan yoksun olarak merkez yeri esası temelinde tanımlanması durumunda faydaların reddi hükmü yoluyla tâbiiyet planlamasının engellenmesi güçleşecek, buna mukabil yatırımcı konusunda daraltıcı bir tanıma başvurulması durumunda tâbiiyet planlamasına başvurulması önlenebilecektir.

\section{SONUÇ}

Ticaret şirketlerinin başka bir devlet tâbiiyetini edinmeleri kural

\footnotetext{
150 Sornarajah, s. 137.

151 Plama Consortium Limited v. Republic of Bulgaria, ICSID Case No. ARB/03/24, Decision on Jurisdiction, 8 February 2005, para 157-165; Yukos Universal Limited (Isle of Man) $v$. The Russian Federation, UNCITRAL, PCA Case No. 2005-04/AA227, Interim Award on Jurisdiction and Admissibility, 30 November 2009, para 458.

152 Voon/ Mitchell/ Munro, s. 55.
} 
olarak meşru olmakla birlikte, sırf yatırım tahkimine başvurmak amacıyla gerçekleştirilen tâbiiyet planlaması devletler nezdinde ciddi rahatsızlıklara neden olmuştur. Bu durumun engellenmesi bakımından en uygun çözümün yatırım anlaşmalarında yatırımcı tanımının gözden geçirilmesi olduğunu mütalaa etmekteyiz. Devletler yatırım tahkimine başvurma imkânını yalnızca kaynak ülkede gerçek yönetim merkezi veya esaslı ekonomik faaliyeti bulunan şirketlere tanımak istiyorlar ise, bu hususu herhangi bir duraksamaya yer vermeyecek şekilde anlaşmaya yansıtmayı değerlendirmelidirler. Böylelikle bir yandan hakemlerin yatırım anlaşmalarına taraf âkit devletlerin iradelerine uygun olarak karar vermeleri, diğer yandan ise hakemlerin anlaşmada olmayan kavramları anlaşma içerisine dâhil etme konusunda yaşadıkları tereddütlerin giderilmesi sağlanacaktır. Devletler ilave olarak yatırım anlaşmaları ile tanınan faydaların bazı şirketlere tanınmayacağı konusunda faydaların reddi hükümlerini de anlaşmalara koymayı düşünebilirler. Buna mukabil kanaatimizce yatırım anlaşmalarında yatırımcı tanımı daraltılmadan kuruluş veya merkez yeri esasları yanında faydaların reddi hükmüne yer verilmesi, tereddütleri gidermeyeceği gibi tâbiiyet planlamasına başvurmayı kısıtlama konusunda da sınırlı bir etki doğuracaktır. Özellikle faydaların reddi konusunda ev sahibi devletin uyuşmazlık çıkmazdan evvel bildirim yükümlülügü altında bulunması, bu hüküm kullanımını kısıtlayacaktır.

Hiç şüphesiz yatırım anlaşmalarında yatırımcı tanımının gerçek yönetim merkezi veya esaslı ekonomik faaliyet kriterini içerecek şekilde değiştirilmesi zaman alacaktır. Bu dönem zarfında ise sırf yatırım tahkimine başvurulması amacıyla başvurulan tâbiiyet planlaması hakemler tarafından hakkın kötüye kullanılması yasağ1 içerisinde değerlendirilebilecektir. Buna mukabil kanaatimizce bu noktada yatırımcı şirket tarafından yatırımın başlangıcında veya uyuşmazlık çıkmazdan evvel genel bir riskin bertaraf edilmesi amacıyla gerçekleştirilen tâbiiyet edinimi ile sırf yatırım tahkimine gitmek amacıyla gerçekleştirilen tâbiiyet planlamasını ayırt etmek gerekir. Meşru kabul edilen tâbiiyet edinimi ile meşru kabul edilmeyen tâbiiyet planlaması arasındaki sınır ise tâbiiyet planlamasının amacı ve zamanlaması dikkate alınarak çizilebilecektir.

\section{KAYNAKÇA}

\section{Makale, Kitap ve Dokümanlar}


Albayrak G, "Diplomatik Koruma Hakkında Taslak Maddeler (Draft Articles On Diplomatic Protection)", Y11 4, 2019/2, YBHD, s. 501-507.

Akıncı Z, Milletlerarası Tahkim, 5. Baskı, Vedat Kitapçılık, 2020.

Arat T, Ticaret Şirketlerinin Tâbiiyeti, Sevinç Matbaası, 1970.

Aybay R/ Özbek N/ Ersen Perçin G, Vatandaşlık Hukuku, Siyasal Kitapevi, 2019.

Aygül M, Uluslararası Özel Hukukta Şirketlere Uygulanacak Hukukun Tespiti, Seçkin Yayınları, 2007.

Becht M/Mayer C/ Wagner H.F, Where Do firms Incorporate? Deregulation and the Cost of Entry, European Corporate Governance Institute, Working Paper 70/2006, 2007.

Berki O.F, Devletler Hususi Hukuku, Cilt I, Yedinci Baskı; Güzel Sanatlar Matbaas1, 1970.

Adam Boczek, Flags of Convenience: An International Legal Study, Harward University Press, 1962.

Casas M, "Nationalities of Convenience, Personal Jurisdiction, and Access to Investor-State Dispute Settlement”, 2016, 49 (1), New York University Journal Of International Law And Politics, s. 63-127.

Crawford J, Brownlie's Principles of Public International Law, Ninth Edition, Oxford Publishing, 2019.

Demirkol B, "Yatırım Tahkiminde Paravan Şirketlerin Yol Açtı̆̆ Yetki Sorunları", 2012, 28 (3), Banka ve Ticaret Hukuku Dergisi, 301-357.

Doğan V, Türk Vatandaşlık Hukuku, 16. (Tıpkı) Bask1, Savaş Yayınevi, 2020.

Draft Articles on Diplomatic Protection with Commentaries, Int'l Law Comm'n, U.N. Doc. A/61/10, 2006.

Esen E, Milletlerarası Özel Hukukta Tüzel Kişilik Perdesinin Kaldırılması, 2. Baskı, Beta Yayınları, 2012.

Erten R, “ICSID Tahkimi”, 1998, 19(4), Banka ve Ticaret Hukuku Dergisi, s. 207-230.

Feldman M, "Setting Limits on Corporate Nationality Planning in Investment 
Treaty Arbitration", 2012, 27(2) ICSID Review, s. 281-302.

Foote S.QC, The Bona Fide Investor: Corporate Nationality and Treaty Shopping in Investment Treaty Law, PhD Thesis, Victoria University of Wellington, Faculty of Law, 2020.

Fatouros A, "National Legal Persons In International Law" in Rudolf L. Bindschedler, Thomas Buergenthal, Karl Doehrıng, Jochen Abr. Froweın, Günther Jaenıcke, Herbert Miehsler, Hermann Mosler, Frıtz Münch, Daniel P. O'connell, Karl Josef Partsch, P1erre Pescatore, Henry G. Schermers, Ulrıch Scheuner, Hans-Jürgen Schlochauer, Max Sørensen, Helmut Strebel (Eds.), Encyclopedia Of Disputes Installment, Elsevier, 1987, s. 299-306.

Göger E, Türk Tâbiiyet Hukuku, Dördüncü Bası, Sevinç Matbaası 1979.

Gölcüklü İ, “ICSID Tahkiminde Yetkiden Kaynaklanan Bazı Sorunlar”, 2018, 38(2), Milletlerarası Hukuk ve Milletlerarası Özel Hukuk Bülteni, s. 285-309.

Güngör G, Tâbiiyet Hukuku, 8. Bası, Yetkin Yayınları, 2020.

Happ R, "Denial of Benefits Clauses and any other Mechanisms that Limit the Scope of BITs for Investors" in The Determination of the Nationality of Investors under Investment Protection Treaties, Institute of Economic Law (Transnational Economic Law Research Center), 2011, s. 61-68.

Janig P, "Cynicism and Nationality Planning in International Investment Law", in Björnstjern Baade - Dana Burchardt/ Prisca Feihle/ Alicia Köppen/ Linus Mührel/ Lena Riemer/ Raphael Schäfer (Eds.), Cynical International Law?. Beiträge zum ausländischen öffentlichen Recht und Völkerrecht (Veröffentlichungen des Max-Planck-Instituts für ausländisches öffentliches Recht und Völkerrecht), vol 296, Springer, 2021, s. 309-326.

Kaya T, "Uluslararası Ticaret ve Yatırım Hukuku Bakımından Tütün Ürünlerinin Düz Paketlenmesi Meselesi”, 2018, 24(2), Marmara Üniversitesi Hukuk Fakültesi Hukuk Araştırmaları Dergisi, s. 10451085.

Kim S.M/ Kim J, "Flags of Convenience in the Context of the OECD BEPS Package", 2018, 49(2), Journal of Maritime Law \& Commerce, s. 221238. 
McLachlan C/ Shore L/ Weiniger M, International Investment Arbitration: Substantive Principles, 2nd Edition, 2017.

Niboyet J.P, "Şirketlerin Hakikaten Bir Tâbiiyeti Mevcut Mudur?", (Çev: Hicri Fişek), 1952, 9(3), Ankara Üniversitesi Hukuk Fakültesi Dergisi, s. 97-113.

Nomer E, Türk Vatandaşlık Hukuku, 27. Baskı, Filiz Kitapevi, 2020.

Perkams M, "The Definition of Nationality of Investors in. International Investment Agreement (IIAs) - Taking Stock of the. Criteria Used in Modern Investment Law" in The Determination of the Nationality of Investors under Investment Protection Treaties, Institute of Economic Law (Transnational Economic Law Research Center), 2011, s. 13-24.

Radi Y, Rules and Practices of International Investment Law and Arbitration (Law in Context). Cambridge: Cambridge University Press, 2020.

Seelig M.L/ Sessler A/ Paulsen H, "Impact of MoMiG on "Sitztheorie"/"Grün dungstheorie" - Consequences for German BITs" in The Determination of the Nationality of Investors under Investment Protection Treaties, Institute of Economic Law (Transnational Economic Law Research Center), 2011, s. 25-36.

Sinclair A.C., "ICSID's Nationality Requirements", 2018, 23(1), ICSID Review - Foreign Investment Law Journal, s. 57-118.

Schreuer C, "Nationality Planning" in Arthur W. Rovine (Ed), Contemporary Issues in International Arbitration and Mediation: Contemporary Issues in International Arbitration and Mediation: The Fordham Papers, 2012, s. $15-27$.

Schreuer C/ Malintoppi L/ Reinisch A/ Sinclair A, A Commentary on the Convention on the Settlement of Investment Disputes between States and Nationals of Other States, Second Edition, 2009.

Sornarajah S, "Good Faith, Corporate Nationality, and Denial of Benefits", in Andrew D Mitchell/ M Sornarajah/ Tania Voon (eds), Good Faith and International Economic Law, Oxford University Press, 2015, s. 117-142.

Söyler Y, "Barcelona Traction Davası ve Uluslararası Hukuka Etkisi", 2015, 19(3), Ankara Hacı Bayram Veli Üniversitesi Hukuk Fakültesi Dergisi, s. 207-247. 
Tekinalp G, Türk Hukukunda Ortaklıkların Vatandaşlığı, İstanbul Üniversitesi Hukuk Fakültesi 50. Yıl Armağanı, Cumhuriyet Döneminde Hukuk, Fakülteler Mahallesi, 1973.

Tiryakioğlu B, "Yatırımlar ve Uluslararası Tahkim Arasındaki İlişki”, 2007, 1(2), Uluslararası Ekonomi ve Dış Ticaret Politikaları, s. 169-184.

UNCTAD, World Investment Report Investor Nationality: Policy Challenges, 2016.

Voon T/ Mitchell A/ Munro J, "Legal Responses to Corporate Manoeuvring in International Investment Arbitration", 2014, 5(1), Journal of International Dispute Settlement, s. 41-68.

Zhang X.J, "Proper Interpretation of Corporate Nationality under International Investment Law to Prevent Treaty Shopping", 2013, 6(1), Contemporary Asia Arbitration Journal, s. 49-74.

\section{Mahkeme ve Hakem Kararları}

Alps Finance and Trade AG v. The Slovak Republic, UNCITRAL, Award, 5 March 2011.

Barcelona Traction, Light \& Power Co., Ltd. (New Application: 1962) (Belg. v. Spain), Judgment,1970 I.C.J. Rep. 3.

Burimi SRL v Albania, ICSID Case No ARB/11/18, IIC 593, Award, 29 May 2013.

Champion Trading Company and Ameritrade International, Inc. v. Arab Republic of Egypt (ICSID Case No. ARB/02/9), Decision on Jurisdiction, 21 October 2013

CMS Gas Transmission Co. v. Argentine Republic, ICSID Case No. ARB/01/8, Decision of the Tribunal on Objections to Jurisdiction, 17 July 2003.

Gold Reserve Inc. v. Bolivarian Republic of Venezuela, ICSID Case No. ARB(AF)/09/1, Award, 22 September 2014.

Hutley Enterprises Ltd v Russia PCA Case No AA 226, IIC 415 UNCITRAL, Interim Award on Jurisdiction and Admissibility, 30 November 2009.

KT Asia Investment Group BV v Kazakhstan, ICSID Case No ARB/09/8, IIC 615, Award, 2013. 
Mobil Cerro Negro Holding, Ltd. v. Venezuela, ICSID Case No. ARB/07/27, Decision on Jurisdiction, 10 June 2010.

Nationality Decrees Issued in Tunis and Morocco, (French Zone), Advisory Opinion, PCIJ Reports, Series B, No. 4.

Pac Rim Cayman LLC v. Republic of El Salvador, ICSID Case No. ARB/09/12, Decision on the Respondent's Jurisdictional Objections, 1 June 2012.

Philip Morris Asia Limited v. The Commonwealth of Australia, UNCITRAL, PCA Case No. 2012-12, Award on Jurisdiction and Admissibility, 17 December 2015.

Phoenix Action, Ltd. v. The Czech Republic, ICSID Case No. ARB/06/5, Award, 15 April 2009.

Plama Consortium Limited v. Republic of Bulgaria, ICSID Case No. ARB/03/24, Decision on Jurisdiction, 8 February 2005.

Yukos Universal Limited (Isle of Man) v. The Russian Federation, UNCITRAL, PCA Case No. 2005-04/AA227, Interim Award on Jurisdiction and Admissibility, 30 November 2009.

Orascom TMT Investments S.à r.l. v. People’s Democratic Republic of Algeria, ICSID Case No. ARB/12/35, Final Award, 2017.

Saluka Investments BV v. The Czech Republic, (UNCITRAL) PCA Case No. 2001-04, Partial Award, 17 March 2006.

Tenaris S.A. and Talta - Trading e Marketing Sociedade Unipessoal Lda. v. Bolivarian Republic of Venezuela, ICSID Case No. ARB/11/26, Award, 29 January 2016.

Tidewater v. Venezuela, ICSID Case No. ARB/10/5, Decision on Jurisdiction, 8 February 2013.

The Rompetrol Group N.V. v. Romania, ICSID Case No. ARB/06/3, Decision on the Respondent's Preliminary Objections on Jurisdiction and Admissibility, 18 April 2008.

Tokios Tokelés v. Ukraine, ICSID Case No. ARB/02/18, Decision on Jurisdiction, 29 April 2004.

Tokios Tokelés v. Ukraine, ICSID Case No. ARB/02/18, Dissenting Opinion 
(Chairman Prosper Weil), 29 April 2014.

Venoklim Holding B.V. v. Bolivarian Republic of Venezuela, ICSID Case No. ARB/12/22, Award, 3 April 2015.

\section{Anlaşma, Protokol ve İnternet Kaynakları}

Agreement Between the United States of America, the United Mexican States, and Canada, <https://ustr.gov/sites/default/files/files/agreements/ FTA/USMCA/Text/01-Initial-Provisions-and-General-Definitions.pdf > Erişim Tarihi 28 Mayıs 2021.

Agreement between the Federal Republic of Germany and the Socialist People's Libyan Arab Jamahiriya concerning the Encouragement and Reciprocal Protection of Investments, $<$ https://investmentpolicy.unctad. org/international-investment-agreements/treaty-files/3126/download > Erişim Tarihi 30 Haziran 2021. Erişim Tarihi 30 Haziran 2021

Agreement on Encouragement and Reciprocal Protection of Investments Between the Government of the People's Republic of China and the Government of the Kingdom of the Netherlands, <https:// investmentpolicy.unctad.org/international-investment-agreements/ treaty-files/763/download> Erişim Tarihi 1 Haziran 2021.

ICSID Convention, <https://icsid.worldbank.org/resources/rules-andregulations/convention/overview> Erişim Tarihi 1 Haziran 2021.

Investment Dispute Settlement Navigator, <https://investmentpolicy.unctad. org/investment-dispute-settlement> Erişim Tarihi 30 Haziran 2021. 
